\title{
OH point defects in quartz - a review
}

\author{
Roland Stalder \\ Institut für Mineralogie und Petrographie, Universität Innsbruck, Innrain 52f, 6020 Innsbruck, Austria
}

Correspondence: Roland Stalder (roland.stalder@uibk.ac.at)

Received: 11 November 2020 - Revised: 23 February 2021 - Accepted: 4 March 2021 - Published: 13 April 2021

\begin{abstract}
Research results of the past 6 decades on the incorporation of $\mathrm{OH}$ point defects in quartz are summarised and evaluated in terms of their application to natural samples and processes, and a link between experimental petrology, natural archives, and model calculations is made. A strong focus is put on recent studies on quartz as a rock-forming mineral, as a geochemical and/or petrological tracer, and as a tool for provenance analysis in sediments and sedimentary rocks.

The most relevant defects for natural specimens are generated by coupled substitution involving mono- and trivalent cations, the most prominent being $\mathrm{Li}^{+}, \mathrm{Al}^{3+}$, and $\mathrm{B}^{3+}$. $\mathrm{OH}$ incorporation is rather a function of the availability of trace metals and water than of pressure and temperature, though temperature indirectly influences the incorporation by the solubility of trace metals in the fluid. Pressure has a negative influence on the formation of $\mathrm{OH}$ defects, so the most pure quartzes are probably formed in the deep crust close to the quartz/coesite transition.

Natural quartz grains from the Earth's crust have on average $10 \mathrm{wt}$ ppm (weight parts per million) water ( $5 \mathrm{wt}$ ppm median), but grains with $\mathrm{OH}$ defect contents corresponding to up $250 \mathrm{wt}$ ppm water have been discovered in sedimentary archives, matching the concentration of quartz from high-pressure experiments $<4 \mathrm{kbar}$ under water-saturated conditions in granitic systems. A rough division into three classes is suggested: (1) grains with pristine igneous and/or hydrothermal origin, (2) mildly thermally annealed grains, and (3) strongly dehydrated grains. While samples derived from the currently exposed Scandinavian Shield are dominated by the third class, considerable contributions of the first two classes are found in the younger rock systems in Central Europe. $\mathrm{OH}$ defect contents may be used to estimate mixing ratios for sediments with different sources, provided that a sufficiently large data set exists and that the different sources can be clearly distinguished by their OH inventory. Furthermore, metamorphic overprint leads to a higher degree of equilibration of $\mathrm{OH}$ defects between individual grains and may thus be used as a geothermometer. Finally, $\mathrm{OH}$ defect retention in quartz allows for estimating timescales of volcanic processes.
\end{abstract}

\section{Introduction}

Quartz is formed under nearly all conditions realised within the Earth's crust, ranging from the Earth's surface down to the base of the continents. Depending on crystallisationrelevant physical and chemical parameters (pressure, stress, temperature, temperature gradients, time, presence and composition of melts and fluids) and geological circumstances (cracks and voids in the surrounding rock), the resulting habit and size of quartz crystals is very diverse, ranging from microcrystalline fibrous chalcedony to decimetre- and metresized euhedral crystals. Although both crystal size extremes are not representative of the main portion of quartz as a rockforming mineral (12 vol\% of the Earth's crust; Ronov and Yaroshevski, 1969), they are very prominent in our mind and important to human history because they were used since prehistoric times as precious stones (such as agate, amethyst, and rock crystal) or for tools and weapons (such as flint and rock crystal). Owing to the high appeal to the human eye and the technical applicability in modern times (Jung, 1992a, b), it is understandable that the first systematic studies on "water" in quartz were performed on large hydrothermal (natural or synthetic) crystals. The major portion of quartz, however, forms as millimetre-sized, often anhedral crystals in ig- 
neous systems ( $50 \%$ of the Earth's continental crust consists of felsic igneous rocks (Wedepohl, 1995) that in turn consist of $>20 \%$ quartz). Furthermore, as a hard and chemically resistant mineral, quartz survives weathering and transport and comprises a significant fraction in siliciclastic sediments, sedimentary rocks, and their metamorphic counterparts.

This review summarises early findings on "water" in quartz and its influence on physical properties, followed by a review of theoretical and experimental considerations on $\mathrm{OH}$ point defects, and finally reports recent data on $\mathrm{OH}$ point defects in common quartz as a rock-forming mineral from igneous rocks, metamorphic rocks, and sedimentary archives. As will be outlined in this study, molecular water follows different incorporation laws than $\mathrm{OH}$ point defects, and, consequently, the wealth of studies on fluid inclusions in quartz, as well as on $\mathrm{OH}$ species (molecular water and $\mathrm{OH}$ point defects) in microcrystalline and/or amorphous silica such as opal and chalcedony (Langer and Flörke, 1974; Frondel, 1982; Adams et al., 1991; Chauviré et al., 2017) and moganite (Flörke et al., 1984; Heaney and Post, 1992; Hardgrove and Rogers, 2013), are not considered in this review.

\section{Brief history}

The existence of a significantly polarised absorption band at $3400 \mathrm{~cm}^{-1}$ with a more pronounced absorption for $E \| o$ than $E \| e$ has been known since the end of the 19th century (Merritt, 1895) but was not linked to a specific impurity until several decades later. In the first half of the 20th century quartz became more and more interesting for the upcoming electronic industries (e.g. chronometry and radio engineering), and research on physical properties and chemical impurities of (preferentially large) natural and synthetic quartz crystals was promoted. The analysis of "water" in quartz reached its first prime in the early 1960s (Bambauer, 1961; Brunner et al., 1961; Kats, 1962; Bambauer et al., 1962, 1963), focussed on detailed investigations on the spatial distribution of chemical impurities, hydrogen mobility, charge balance, and assignment of infrared (IR) absorption bands to specific $\mathrm{OH}$ defects in natural hydrothermal quartzes. Although a distinction between different species such as molecular water and $\mathrm{OH}$ point defects (protons that are charge balanced by metal impurities or vacancies) was made, both species were often subsumed as water. The research on water in quartz was further fuelled by the discovery of hydrolytic weakening (Carter et al., 1964; Griggs and Blacic, 1965; Griggs et al., 1966) and its importance for structural geology. In the following decades research on $\mathrm{OH}$ in quartz experienced several flares accompanying technical improvements of microanalysis, such as secondary ion mass spectrometry (Rovetta et al., 1989), transmission electron microscopy (Gerretsen et al., 1989; Cordier and Doukhan, 1991), and calculation capacities (Purton et al., 1992; McConnell et al., 1995; Rosa et al., 2005). Predominant study objects during these periods still were large hydrothermal (natural and synthetic) single crystals. It was not until the early 21 st century that common quartz - representing the main portion of quartz as a rock forming mineral - came into focus, and systematic studies on metamorphic (Müller and Koch-Müller, 2009), sedimentary (Stalder and Neuser, 2013; Stalder, 2014; Stalder et al., 2017, 2019; Jaeger et al., 2019), volcanic (Biró et al., 2016, 2017), and plutonic (Müller et al., 2009; Stalder et al., 2017; Potrafke et al., 2020) quartz grains were performed.

\section{Dry and hydrous point defects in quartz}

Impurities in quartz can be incorporated by a plethora of cation exchanges, either by the simple exchange of $\mathrm{Si}^{4+}$ by other tetravalent cations such as $\mathrm{Ti}^{4+}$ or $\mathrm{Ge}^{4+}$ or by coupled substitutions involving monovalent cations such as alkalis or protons. Within the scope of this work, defects involving protons are called "hydrous defects", and those without protons are called "dry defects".

Even before quartz was systematically investigated for impurities and chemical zoning, it was known that $\beta$-eucryptite $\left(\mathrm{LiAlSiO}_{4}\right)$ is isostructural to high quartz (Winkler, 1948; Cohen, 1960; London, 1984) and that a metastable solid solution series exists in the system $\mathrm{SiO}_{2}-\mathrm{LiAlO}_{2}$ (Roy and Osborn, 1949), indicating the possibility of a "dry" AlLi defect through the exchange $\mathrm{Si}^{4+}=\mathrm{Al}^{3+}+\mathrm{Li}^{+}$. Consequently, the first charge balance equations involving incorporation of defect protons into the quartz structure considered $\mathrm{Al}^{3+}$ and alkali cations as the most relevant impurities (Bambauer, 1961; Kats, 1962, Chakraborty and Lehmann, 1976a). Other tri- and pentavalent cations were subsequently added to the equation, suggesting a charge balance equation,

$\left[\mathrm{Al}, \mathrm{B}, \mathrm{Fe}^{3+}\right]=[\mathrm{H}, \mathrm{Na}, \mathrm{K}, \mathrm{Li}, \mathrm{P}]$,

for natural samples (Müller and Koch-Müller, 2009) that later was confirmed for experimentally grown quartz crystals from natural starting material (Baron et al., 2015; Potrafke et al., 2019, 2020), while a modified equation for small $\mathrm{Li}$ contents and crystallisation at moderate pressure $(<10 \mathrm{kbar})$ was proposed $[\mathrm{Al}, \mathrm{B}, \mathrm{Li}]=[\mathrm{H}, \mathrm{Na}, \mathrm{K}, \mathrm{P}]$, taking into account a neutral LiOH species (Frigo et al., 2016).

Large hydrothermal quartz crystals are very heterogeneous with respect to OH (Kats, 1962), and the highest concentrations are often found in the centre of the crystal (Chakraborty and Lehmann, 1976a). A similar systematic zoning from core to rim was observed for metal impurities such as $\mathrm{Al}^{3+}$ (Müller et al., 2003; Miyoshi et al., 2005), suggesting that metal impurities are linked to $\mathrm{OH}$ defects and that the impurity incorporation is controlled by the fluid chemistry and growth rate. Strong chemical zoning was recently also discovered within individual phenocrysts from the Mesa Falls Tuff pyroclastic succession (Tollan et al., 2019) and from Bishop Tuff (Jollands et al., 2020b), where a decrease in OH from core to rim mirrored a strong zoning for $\mathrm{Al}$ and the for- 
mation of a "dry" LiAl defect at the outermost rim by the exchange of $\mathrm{H}$ by Li.

\section{Hydrous species in quartz}

As a chemical component, water in quartz is hosted in at least two totally different ways: (1) molecular water such as fluid inclusions and (2) OH point defects, in which protons are charge balanced by vacancies or metal impurities. Further hosts of water are micro inclusions of melts and hydrous minerals such as mica (Stalder and Neuser, 2013; Kronenberg et al., 2017), as well as amorphous gel-like material (Brunner et al., 1961). The different OH species were identified and characterised by a number of different strategies, such as freezing behaviour, D/H exchange, and absorption features in the IR region. Amorphous gel-like material, for example, causes a rather broad, isotropic absorption band at 3400 or $3500 \mathrm{~cm}^{-1}$ and leads to the formation of molecular water upon heat treatment $\left(2 \mathrm{SiOH}=\mathrm{Si}-\mathrm{O}-\mathrm{Si}+\mathrm{H}_{2} \mathrm{O}\right)$ that gives the crystal a milky appearance (Bambauer et al., 1969). It further does not show evidence for H/D exchange (Brunner et al., 1961) and probably is formed during low temperature processes. Such absorption bands are typical for precious varieties of quartz such as amethyst, citrin, and rock crystal (Chakraborty and Lehmann, 1976b).

It has already been repeatedly mentioned since the first studies that molecular water (mostly as fluid inclusions) is the dominant $\mathrm{OH}$ species in quartz (Bambauer, 1961; Aines et al., 1984; Gerretsen et al., 1989; Cordier and Doukhan, 1991; Müller and Koch-Müller, 2009; Kronenberg et al., 2017) and that these fluid inclusions in turn are strongly enriched in alkalis (Bambauer, 1961; Müller et al., 2003). Some of the molecular water is hosted in nano-inclusions (Gerretsen et al., 1989; Cordier and Doukhan, 1991) that are often too small to build ice upon freezing (Aines and Rossman, 1984; Müller and Koch-Müller, 2009). Furthermore, no correlation could be found between the amount of molecular water incorporation and $\mathrm{OH}$ point defects (Aines et al., 1984; Biró et al., 2016), which implies that the amount of molecular water in quartz is not a diagnostic for the formation conditions and thermal history of an individual grain. While point defect formation is controlled by thermochemical parameters (Paterson, 1986), the amount of fluid inclusions is often heterogeneously distributed even within one individual and otherwise chemically homogeneous grain. Fluid inclusions are often concentrated along healed cracks and were taken up under deformation, which in early studies led to estimates of water solubility that are too high (Gerretsen et al., 1989). Therefore, the present article will be focused on $\mathrm{OH}$ point defects, and molecular water will not be discussed in detail.

Proton incorporation as $\mathrm{OH}$ defects leads to the formation of characteristic $\mathrm{OH}$ dipoles that can be detected and distinguished depending on the charge compensation by their absorption frequency in the IR range of electromagnetic radia- tion. Since oxygen is the only charge-balancing anion in the crystal, the relevant geochemical component in mineralogical and petrological literature is often expressed as a neutral water component. Therefore, throughout this article $\mathrm{OH}$ contents are expressed as weight parts per million (wt ppm) water (identical to $\mu \mathrm{g} / \mathrm{g} \mathrm{H}_{2} \mathrm{O}$ ), in which $0.01 \mathrm{wt} \%$ water corresponds to $100 \mathrm{ppm}$ water, $11.1(=100 / 9) \mathrm{ppm} \mathrm{H}$, or 667 $(=100 / 0.15) \mathrm{H} / 10^{6} \mathrm{Si}$.

\section{Methods to characterise and quantify $\mathrm{OH}$ in quartz}

Although several different instrumental methods to measure $\mathrm{OH}$ in nominally anhydrous minerals has been established, the by far most used technique to analyse $\mathrm{OH}$ in quartz is IR spectroscopy that detects absorption of IR radiation due to vibrations in the respective material. Different structural environments differ in their bond strength, length, and orientation and thus have different vibration properties. Based on the absorption band characteristics such as vibration frequency, anisotropy, and band sharpness (Fig. 1a), IR spectroscopy is able to distinguish between different $\mathrm{OH}$ species, such as (1) molecular water, (2) nominally OH-bearing minerals, and (3) several specific $\mathrm{OH}$ point defects. Since the absorbance is linearly correlated to the concentration (Eq. 2), the sensitivity depends on the sample thickness, and for $200 \mu \mathrm{m}$ thick sections of crystals a detection limits down to the parts per million (ppm) level can be reached. For thicker samples even lower concentrations can be detected. Analysis can now be performed on surfaces below $0.001 \mathrm{~mm}^{2}$ (compared to $10 \mathrm{~mm}^{2}$ in early studies such as Brunner et al., 1961), enabling the possibility to reveal micrometre-sized colourless inclusions (Stalder and Neuser, 2013) and complex internal zonings (Potrafke et al., 2020). In order to turn IR absorptions into concentrations, $\mathrm{OH}$ contents have to be determined by an independent method on reference material, and in the past 6 decades different methods were used, such as (1) H-alkali exchange via electrolysis (Brunner et al., 1961), (2) secondary ion mass spectrometry (Rovetta et al., 1989; Thomas et al., 2009), (3) proton-proton-scattering (Thomas et al., 2009), and (4) the theoretical calculation of extinction coefficients (Balan et al., 2008; Jollands et al., 2020a). The formulations deviate from each other with respect to the measurement protocol (unpolarised versus polarised) and in terms of the resulting units (concentrations expressed as wt ppm water or $\mathrm{H} / 10^{6} \mathrm{Si}$ ), and thus different integral extinction coefficients $\varepsilon$ (Eq. 2) were obtained, which finally all lead to the similar results: the mineral-specific calibration of Thomas et al. (2009) determined a value for the extinction coefficient as $\varepsilon=89000 \pm 15000 \mathrm{~L} \mathrm{~mol}^{-1} \mathrm{~cm}^{-2}$, which is in excellent agreement with $\varepsilon=246.6(3753-v)$ of $\mathrm{Li}$ bowitzky and Rossman (1997) that would receive the same value for $\varepsilon$ for a wavenumber $v=3390 \mathrm{~cm}^{-1}$. As the main absorption band of $\mathrm{OH}$ in quartz is exactly in this region for most quartz specimens, both calibrations obtain nearly iden- 

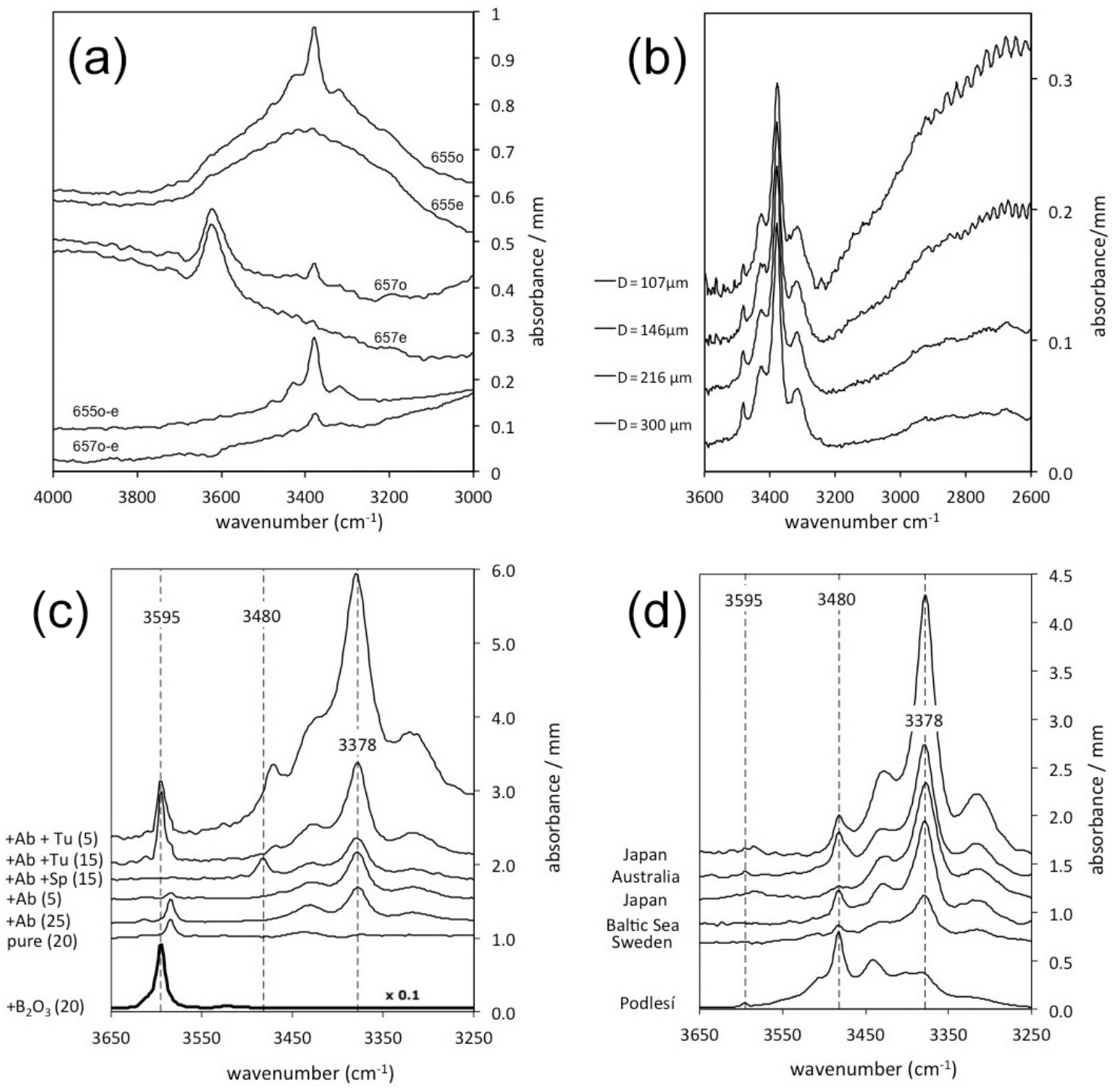

Figure 1. IR spectra of quartz normalised to $1 \mathrm{~mm}$ thickness. Spectra are offset for graphical reasons. (a) Polarised $\left(E \| n_{\mathrm{o}}\right.$ and $\left.E \| n_{\mathrm{e}}\right)$ spectra of quartz grains (\#655 and \#657) from granites from Vånga, Sweden (Stalder et al., 2017), showing strong absorptions for molecular water around $3400 \mathrm{~cm}^{-1}$ (\#655) and mica inclusions around $3620 \mathrm{~cm}^{-1}$ (\#657). By subtraction of both spectra $\left(E\left\|n_{\mathrm{o}}-E\right\| n_{\mathrm{e}}\right)$ the isotropic signal is erased, and the absorption feature for the $\mathrm{OH}$ defects $(655 \mathrm{o}-\mathrm{e}$ and $657 \mathrm{o}-\mathrm{e})$ is extracted. This procedure was followed in all other spectra in (b)-(d). (b) Quartz grain from a granite from Vånga, Sweden (Stalder et al., 2017). The grain was repeatedly thinned out and re-measured. (c) Quartz crystals grown in high-pressure experiments from Stalder and Konzett (2012), Baron et al. (2015), Frigo et al. (2016), and unpublished results. Added phases to the starting material are Ab (albite), Sp (spodumene), and Tu (tourmaline), and numbers in parentheses indicate the pressure in kilobars (kbar). Impurity-specific absorption bands (at 3378, 3480, and $3595 \mathrm{~cm}^{-1}$ ) are indicated by broken lines. Note that the sample from the $\mathrm{B}_{2} \mathrm{O}_{3}$ doped run was further minimised by a factor of 10 for graphical reasons. (d) OH-rich natural quartz crystal from a pegmatitic quartz (Podlesí, Czech Republic; Breiter et al., 2005) compared to crystals from sedimentary archives reported in Jaeger et al. (2019) for Japan, Stalder (2014) for Australia and Sweden, and Stalder et al. (2017) for the Baltic Sea. Impurity-specific absorption bands (at 3378, 3480, and $3595 \mathrm{~cm}^{-1}$ ) are indicated by broken lines. The LiOH band $\left(3480 \mathrm{~cm}^{-1}\right)$ is typically dominant in the pegmatitic sample but poorly preserved in the sedimentary grains. 
tical results. Only in a few cases in which high-wavenumber bands are over-represented (Stalder and Konzett, 2012) does the wavenumber-dependent calibration lead to systematically higher $\mathrm{OH}$ concentrations. Considering that $\mathrm{OH}$ dipoles are nearly totally polarised $\| n_{\mathrm{o}}$ (perpendicular to the $c$ axis) and using the Lambert-Beer equation,

$c=\frac{A}{t \cdot \varepsilon}$

with the concentration $c$, the extinction coefficient $\varepsilon$, and the thickness normalised absorbance $A / t$, Thomas et al. (2009) would receive for one polarised measurement $\| n_{\mathrm{o}}$ the relation

$c\left(\mathrm{ppmH}_{2} \mathrm{O}\right)=\frac{A}{t} \cdot \frac{2 \cdot M_{\mathrm{H}_{2} \mathrm{O}} \cdot 1000}{D_{\mathrm{Qz}} \cdot 89000}=\frac{A}{t} \cdot 0.153$,

with the molar mass of water $M=18 \mathrm{~g} \mathrm{~mol}^{-1}$, the density of quartz $D=2.65 \mathrm{~g} \mathrm{~cm}^{-3}$, and the thickness $t$ in centimetres. The factor 2 represents the twofold contributions of $n_{\mathrm{o}}$ (out of the three directions in space), and the factor 1000 is obtained from the conversion of litres to cubic centimetres $\left(\mathrm{cm}^{3}\right)$. The obtained value is equivalent to

$c\left(\frac{H}{10^{6} \mathrm{Si}}\right)=\frac{A}{t} \cdot 1.02$,

while Aines et al. (1984) receive only very slightly higher values:

$c\left(\frac{H}{10^{6} \mathrm{Si}}\right)=\frac{A}{t} \cdot 1.05$.

Taking into account the different measurement protocols and different units, the extinction coefficients of $\varepsilon=$ $14000 \mathrm{~cm} \mathrm{~mol}^{-1}$ used by Brunner et al. (1961), Bambauer (1961), and Chakraborty and Lehmann (1976a) would be recalculated to the sixfold value $\varepsilon=84000 \mathrm{~L} \mathrm{~mol}^{-1} \mathrm{~cm}^{-2}$, which is in excellent agreement with the other calibrations. The mineral-specific calibration of Rovetta et al. (1989) leads to $30 \%$ higher $\mathrm{OH}$ contents. There is an ongoing debate whether a mineral- or wavenumber-specific calibration is more reliable. On the one hand, a pronounced dependence of the extinction coefficient on the wavenumber for $\mathrm{OH}$ dipoles in quartz was theoretically predicted by density functional theory (DFT) calculations (Balan et al., 2008; Jollands et al., 2020a), and a nearly linear correlation has been observed for $\mathrm{OH}$ dipoles in hydrous minerals (Libowitzky and Rossman, 1997). On the other hand, a less pronounced dependence was observed for different $\mathrm{OH}$ absorption bands in quartz in the calibration of Thomas et al. (2009), and finally, one mineralspecific extinction coefficient of $89000 \mathrm{~L} \mathrm{~mol}^{-1} \mathrm{~cm}^{-2}$ was proposed. While the theoretically calculated extinction coefficients (Balan et al., 2008; Jollands et al., 2020a) are significantly higher than suggested by the analytical calibrations and would lead to lower $\mathrm{OH}$ concentrations by up to a factor a
2, the general wavenumber-specific (and not quartz-specific) calibration of Libowitzky and Rossman (1997) leads nearly to identical $\mathrm{OH}$ contents for most samples compared to the mineral-specific calibrations of Brunner et al. (1961) and Thomas et al. (2009). Since all calibrations finally obtain very similar $\mathrm{OH}$ contents, no a posteriori corrections concerning the originally published values were made in the data compilation (Table 1) of published $\mathrm{OH}$ contents in quartz. A more complicating factor for the comparison of published data from different references is the circumstance that some studies did not make a distinction between molecular water and $\mathrm{OH}$ from point defects, leading to higher $\mathrm{OH}$ for some samples, especially those in which molecular water was an important species. Since molecular water gives rise to broad isotropic absorption bands and hydrous defects are nearly perfectly polarised $\| n_{\mathrm{o}}$ (Brunner et al., 1961), a distinction between both fundamentally different groups of species was made early by only taking into account the sharp polarised absorption bands (Bambauer et al., 1962) or by the separate quantification of point defects and molecular water (Müller and Koch-Müller, 2009; Biró et al., 2016). Another strategy to overcome the contribution of non-defect $\mathrm{OH}$ (actually originally proposed by Brunner et al., 1961) is a revised protocol for the treatment of IR absorption spectra (Stalder and Konzett, 2012), in which all measurements are performed on oriented sections $\| c$ for both crystallographic directions $\left(E \| n_{\mathrm{o}}\right.$ and $\left.E \| n_{\mathrm{e}}\right)$ on the same spot. Subtraction of both spectra $\left(E\left\|n_{\mathrm{o}}-E\right\| n_{\mathrm{e}}\right)$ eliminates the isotropic contributions of molecular water, hydrous melts, and randomly oriented mica inclusions (Fig. 1a). For the $\mathrm{BOH}$ defect that exhibits one third of its absorbance $\| n_{\mathrm{e}}$, the proposed protocol was later refined (Stalder and Neuser, 2013; Baron et al., 2015). This strategy is in general in accordance with many previous studies, in which all measurements were performed $\| n_{\mathrm{o}}$ (Bambauer, 1961) and/or only the contribution $\| n_{\mathrm{o}}$ was used for OH quantification (Brunner et al., 1961; Aines et al., 1984). Besides the $\mathrm{OH}$ absorption bands, IR spectroscopy also reveals information on the orientation and thickness of a sample by using lattice overtones (Biró et al., 2016; Stalder et al., 2017; Jollands et al., 2020b) and offers an independent alternative to mechanical measurements of the sample thickness that is needed to calculate concentrations from the measured absorbance (Eq. 2).

\section{IR band assignment and their chemical correlation to metal impurities}

Several dozens of $\mathrm{OH}$ absorption bands in quartz have been reported in the literature (for a summary see Aines and Rossman, 1984) and linked to specific defect species based on chemical correlations, thermal stability, H/D exchange experiments, and spectral characteristics such as sharpness and polarisation. It is understandable that reported band positions deviate from each other by some wavenumbers due 
Table 1. $\mathrm{OH}$ defects in natural quartz samples.

\begin{tabular}{|c|c|c|c|c|c|c|c|}
\hline \multirow[t]{2}{*}{ Source material } & \multirow[t]{2}{*}{ Method } & \multirow{2}{*}{$\begin{array}{l}\text { Number } \\
\text { samples }^{\mathrm{a}}\end{array}$} & \multirow{2}{*}{$\begin{array}{l}\text { Number } \\
\text { crystals }\end{array}$} & \multicolumn{3}{|c|}{ OH defects (as wt ppm water) } & \multirow[t]{2}{*}{ Reference } \\
\hline & & & & Range min & Range max & Average & \\
\hline Granite & FTIR & 2 & & 13 & 13 & 13 & Müller and Koch-Müller (2009) \\
\hline Granite & FTIR & & 6 & 4 & 18 & 10 & Stalder and Neuser (2013) \\
\hline Granite & FTIR & & 132 & $<1$ & 28 & 5 & Stalder et al. (2017) \\
\hline Granite & FTIR & & 100 & 9 & 72 & 26 & Potrafke et al. (2020) \\
\hline Pegmatite & SIMS & & 1 & 22 & 22 & 22 & Yurimoto et al. (1989) \\
\hline Pegmatite & FTIR & 3 & & 6 & 45 & 20 & Müller and Koch-Müller (2009) \\
\hline Pegmatite & FTIR & & 2 & 3 & 5 & 4 & Stalder and Neuser (2013) \\
\hline Comb quartz & FTIR & & 1 & 132 & 132 & 132 & Breiter et al. $(2005)^{b}$ \\
\hline Smoky quartz ${ }^{\mathrm{c}}$ & FTIR & & 9 & $<1$ & 3 & 1 & Bambauer (1961) \\
\hline Smoky quartz ${ }^{\mathrm{c}}$ & FTIR & & 70 & $<1$ & 6 & 1 & Bambauer et al. (1962) \\
\hline Rock crystal ${ }^{c}$ & FTIR & & 13 & $<1$ & 8 & 2 & Bambauer (1961) \\
\hline Rock crystal $^{c}$ & FTIR & & 1 & 15 & 15 & 15 & Stalder and Neuser (2013) \\
\hline "Common" quartz ${ }^{\mathrm{c}}$ & FTIR & & 295 & $<2$ & 10 & 3 & Bambauer et al. (1962) \\
\hline Mimetic quartz ${ }^{\mathrm{c}}$ & FTIR & & 11 & 10 & 180 & 70 & Bambauer (1961) \\
\hline Mimetic quartz ${ }^{\mathrm{c}}$ & FTIR & & 60 & 7 & 225 & 50 & Bambauer et al. (1962) \\
\hline Hydrothermal & FTIR & & 2 & 2 & 28 & 15 & Kats (1962) \\
\hline Hydrothermal & SIMS & & 5 & 5 & 40 & 20 & Rovetta et al. (1989) \\
\hline Hydrothermal & SIMS & & 6 & 18 & 38 & 28 & Yurimoto et al. (1989) \\
\hline Hydrothermal & FTIR & & 1 & 7 & 40 & 20 & Miyoshi et al. (2005) \\
\hline Hydrothermal & FTIR & 2 & & 6 & 8 & 7 & Müller and Koch-Müller (2009) \\
\hline Rhyolite & FTIR & & 6 & 1 & 12 & 7 & Stalder and Neuser (2013) \\
\hline Rhyolite & FTIR & 4 & & 1 & 3 & 2 & Biró et al. (2016) \\
\hline Rhyolite & FTIR & 8 & & 3 & 13 & 10 & Biró et al. (2017) \\
\hline Quartzite & FTIR & 7 & & 4 & 12 & 8 & Müller and Koch-Müller (2009) \\
\hline Quartzite & FTIR & & 6 & 1 & 2 & 2 & Stalder and Neuser (2013) \\
\hline Quartzite & FTIR & & 145 & $<1$ & 10 & 2 & Stalder et al. (2017) \\
\hline Gneiss & FTIR & & 1 & 2 & 2 & 2 & Stalder and Neuser (2013) \\
\hline Eclogite & FTIR & & 2 & 3 & 3 & 3 & Stalder and Neuser (2013) \\
\hline Siliciclastic sediments & FTIR & & 95 & $<1$ & 50 & 15 & Stalder and Neuser (2013) \\
\hline Siliciclastic sediments & FTIR & & 338 & $<1$ & 155 & 9 & Stalder (2014) \\
\hline Siliciclastic sediments & FTIR & & 246 & $<1$ & 114 & 16 & Stalder et al. (2017) \\
\hline Siliciclastic sediments & FTIR & & 543 & $<1$ & 65 & 11 & Stalder et al. (2019) \\
\hline Siliciclastic sediments & FTIR & & 188 & $<1$ & $257^{\mathrm{d}}$ & 9 & Jaeger et al. (2019) \\
\hline
\end{tabular}

FTIR signifies Fourier transform infrared spectroscopy, and SIMS signifies secondary ion mass spectrometry. ${ }^{\text {a }}$ Averaged value of several unpolarised measurements on unoriented crystals; ${ }^{\mathrm{b}} \mathrm{OH}$ content determined in this study; ${ }^{\mathrm{c}}$ formed under hydrothermal conditions;

$\mathrm{d}$ value higher than initially reported $(211 \mathrm{ppm})$ after re-examination.

to different spectrometer calibrations and different temperatures during analysis (e.g. room and liquid nitrogen temperature). A particular example of a band shift is reported for the most prominent $\mathrm{AlOH}$ band at $3378 \mathrm{~cm}^{-1}$, which is shifted to $3395 \mathrm{~cm}^{-1}$ at $550^{\circ} \mathrm{C}$ and drops to $3386 \mathrm{~cm}^{-1}$ at the $\alpha / \beta$ transition of quartz at $573{ }^{\circ} \mathrm{C}$ (Suzuki and Nakashima, 1999). During cooling from room temperature to liquid nitrogen temperature, the $\mathrm{AlOH}$ band is shifted by $15-20 \mathrm{~cm}^{-1}$ towards lower wavenumbers, while the $\mathrm{LiOH}$ band at $3470 \mathrm{~cm}^{-1}$ (at room temperature) is only shifted by $10 \mathrm{~cm}^{-1}$ (Brunner et al., 1961; Suzuki and Nakashima, 1999). Therefore, wavenumbers given below may deviate slightly from the values reported in the original publications.
Apart from the aforementioned broad and isotropic absorption feature for molecular water, the most important $\mathrm{OH}$ absorption bands are strongly polarised and have been assigned to specific metal impurities. The by far most important metal impurity is $\mathrm{Al}^{3+}$, followed by $\mathrm{Li}^{+}$and $\mathrm{B}^{3+}$.

\subsection{AlOH band}

The most prominent absorption band occurs at $3378 \mathrm{~cm}^{-1}$ and is accompanied by two side bands at 3310 and $3440 \mathrm{~cm}^{-1}$ (Fig. 1). This band is rather sharp and strongly polarised $\| n_{\mathrm{o}}$ (Kats, 1962), is the most stable band against thermal treatment (Brunner et al., 1961; Bambauer et al., 
1963; Aines and Rossman, 1984), and exhibits the slowest diffusion rates. Based on H/D exchange experiments this band has unequivocally been identified as the $\mathrm{OH}$ absorption band (Kats, 1962), and due to chemical correlations to the $\mathrm{Al}$ content of the sample, this triplet was assigned as the AlOH defect (Bambauer, 1961; Brown and Kahan, 1975; Aines and Rossman, 1984) that results from the coupled substitution $\mathrm{Si}^{4+}=\mathrm{Al}^{3+}+\mathrm{H}^{+}$. The $\mathrm{AlOH}$ defect was also characterised by electron paramagnetic resonance (Halliburton et al., 1981; Nuttall and Weil, 1981), and the band assignment has in general been confirmed by DFT calculations (Jollands et al., 2020a).

\subsection{LiOH band}

The second most pronounced sharp absorption band in most hydrothermal quartz specimens is detected at 3470$3480 \mathrm{~cm}^{-1}$ (Fig. 1). Like AlOH it was identified as the $\mathrm{OH}$ band by $\mathrm{H} / \mathrm{D}$ exchange experiments, and it is strongly polarised $\| n_{\mathrm{o}}$ (Kats, 1962) and accompanied by several side bands between 3400 and $3520 \mathrm{~cm}^{-1}$ (Brunner et al., 1961; Kats, 1962; Aines and Rossman, 1984). Based on chemical correlations it was assigned as the Li-specific defect and is commonly referred to as LiOH (Kats, 1962; Bambauer et al., 1963; Aines and Rossman, 1984). Its incorporation into the crystal lattice was proposed as an interstitial molecule (Kats, 1962; Bambauer et al., 1963), as the Li-perturbed $\mathrm{AlOH}$ band (Kats, 1962), or (equivalently) as the proximity of an $\mathrm{AlOH}$ to a dry AlLi defect (Miyoshi et al., 2005) that also contributes to the high-energy band of the $\mathrm{AlOH}$ triplet at $3440 \mathrm{~cm}^{-1}$. The formation of dry defects, in which $\mathrm{Li}^{+}$concurs with $\mathrm{H}^{+}$, is supported by the general charge balance equation (Eq. 1) (Bambauer, 1961; Müller and KochMüller, 2009) and has recently been documented in quartz phenocrysts interacting with its degassing host magma (Tollan et al., 2019). Upon thermal (or hydrothermal) treatment the $\mathrm{LiOH}$ bands decrease irreversibly while $\mathrm{AlOH}$ increases (Brunner et al., 1961; Rovetta et al., 1986; Kronenberg et al., 1986; Suzuki and Nakashima, 1999; Stalder et al., 2017), suggesting that the $\mathrm{LiOH}$ environment is destroyed, while the $\mathrm{OH}$ is retained in the crystal. As a consequence of the low thermal stability of $\mathrm{LiOH}$, these bands are much weaker (or even absent) in quartz from metamorphic origin (Müller and Koch-Müller, 2009). DFT calculations (Jollands et al., 2020a) corroborate the suggested band assignment.

\subsection{BOH band}

Another frequently observed absorption band occurs at $3595 \mathrm{~cm}^{-1}$ (Fig. 1c) and has been correlated to boron impurities in the crystal lattice forming by the coupled substitution $\mathrm{Si}^{4+}=\mathrm{B}^{3+}+\mathrm{H}^{+}$(Staats and Kopp, 1974; Müller and Koch-Müller, 2009). Its pleochroic behaviour is different from all other impurity-related $\mathrm{OH}$ vibrations, with $E \| n_{\mathrm{o}}$ contributing only two thirds of the total absorbance and $E \| n_{\mathrm{e}}$ contributing one third (Thomas et al., 2009; Stalder, 2014; Baron et al., 2015). Furthermore, it is thermally stable up to $600^{\circ} \mathrm{C}$ (Niimi et al., 1999), and consequently, BOH has a better chance than $\mathrm{LiOH}$ to survive metamorphic overprint. Finally, this band is sharper in natural than in synthetic amethyst and has been used as discrimination tool (Karampelas et al., 2005). The band assignment has been confirmed by DFT calculations (Jollands et al., 2020a).

\subsection{Intrinsic band}

A further absorption band occurs at $3585 \mathrm{~cm}^{-1}$; this band is not relevant for average natural quartz (Stalder, 2014) but frequently observed in synthetic quartz (Chakraborty and Lehmann, 1976a) and natural amethyst (Chakraborty and Lehmann, 1976b; Aines and Rossman, 1984; Karampelas et al., 2005). Due to its occurrence in pure synthetic quartz and its missing correlation to metal impurities leading to an excess $\mathrm{OH}$ in the charge balance equation (Eq. 1), it is widely accepted as an intrinsic defect (Paterson, 1986; Rovetta, 1989; Rovetta et al., 1989; Stalder and Konzett, 2012). There has been some debate concerning its possible or probable assignment as a hydrogarnet $[4 \mathrm{H}]_{\mathrm{Si}}$ defect $(\mathrm{Pa}-$ terson, 1986; Stalder and Konzett, 2012). On the one hand, the theoretically predicted existence of a concentration maximum of $[4 \mathrm{H}]_{\mathrm{Si}}$ (around a pressure of $10-15 \mathrm{kbar}$; Paterson, 1986) has experimentally been reproduced (though at 20 25 kbar; Stalder and Konzett, 2012), and on the other hand, recent DFT calculations suggest that a hydrogarnet defect should lead to four different $\mathrm{OH}$ stretching bands. The preferred explanation for the $3585 \mathrm{~cm}^{-1}$ band from these calculations are isolated $\mathrm{OH}^{-}$groups with non-local charge compensation (Jollands et al., 2020a).

\subsection{Further bands}

A further weak and only occasionally visible band occurs at $3614 \mathrm{~cm}^{-1}$ (Stalder and Konzett, 2012, and unpublished results), potentially related to the $3585 \mathrm{~cm}^{-1}$ band. This band is only visible at very high intrinsic defect concentrations and may additionally be blurred by mica inclusions that exhibit strong absorptions around $3620 \mathrm{~cm}^{-1}$ (Stalder and Neuser, 2013).

In some studies a very weak absorption band was detected at $4500 \mathrm{~cm}^{-1}$ (Brunner et al., 1961; Cordier and Doukhan, 1991) and later was assigned as hydrogarnet (Cordier et al., 1994). Upon thermal treatment it is replaced by an absorption band at $5200 \mathrm{~cm}^{-1}$ (Brunner et al., 1961), which was interpreted as a combination band of molecular water (Cordier and Doukhan, 1991).

Several suggestions for the assignment of a further absorption feature at around $3200 \mathrm{~cm}^{-1}$ have been put forward. Possibly, this band is generated by molecular surface water or Si-O overtones (Biró et al., 2016), and hence it was often ignored for $\mathrm{OH}$ quantification in recent studies. Absorption 
features for the anisotropic contribution $\left(E|| n_{\mathrm{o}}-E \| n_{\mathrm{e}}\right)$ below $3250 \mathrm{~cm}^{-1}$ have, however, to be regarded with caution because their thickness-normalised absorbance changes with thickness (Fig. 1b), which can be explained neither by Si-O overtones (which should stay constant when normalised to thickness), nor by molecular surface water (which should be isotropic).

\section{Thermodynamic modelling and ab initio calculations}

Several attempts have been made to model $\mathrm{OH}$ defect species based on thermodynamics (Doukhan and Trépied, 1985; Paterson, 1986; Rovetta, 1989) and ab initio calculations (Purton et al., 1992; McConnell et al., 1995; Rosa et al., 2005; Jollands et al., 2020a). Until recently calculations were strongly focussed on the two concurring intrinsic defects: hydrogarnet defect $[4 \mathrm{H}]_{\mathrm{Si}}$ and the so called Griggs defect according to the reaction $\mathrm{Si}-\mathrm{O}-\mathrm{Si}+\mathrm{H}_{2} \mathrm{O}=2 \mathrm{SiOH}$ (Griggs et al., 1966). There is consent that $[4 \mathrm{H}]_{\mathrm{Si}}$ concentrations are positively correlated with pressure up to $10 \mathrm{kbar}$ (Doukhan and Trépied, 1985; Paterson, 1986) at oxygen fugacities above NNO-2. As to temperature, both negative (Doukhan and Trépied, 1985) and positive (Paterson, 1986) correlations were predicted. Assuming a $[4 \mathrm{H}]_{\mathrm{Si}}$ formation by the reaction of the dissociated species (Paterson, 1986),

$$
\begin{gathered}
2 \mathrm{H}_{2}(\text { gas })+\mathrm{O}_{2}(\text { gas })+\mathrm{SiO}_{2}(\text { crystal }) \\
=\mathrm{H}_{4} \mathrm{O}_{2}(\text { crystal })+\mathrm{SiO}_{2}(\text { surface }),
\end{gathered}
$$

where $\mathrm{H}_{4} \mathrm{O}_{2}$ (crystal) represents the $[4 \mathrm{H}]_{\mathrm{Si}}$ defect. It was predicted that $[4 \mathrm{H}]_{\mathrm{Si}}$ concentrations drop to nearly zero below oxygen fugacities of NNO-6 (Paterson, 1986). Similarly, thermodynamic models for the Griggs-type $\mathrm{SiOH}$ defect calculated for pressure conditions at $15 \mathrm{kbar}$ suggest increasing concentrations with decreasing oxygen fugacity and a positive correlation to temperature (Rovetta, 1989) and maximum $\mathrm{OH}$ concentrations corresponding to up to $300 \mathrm{wt}$ ppm water. $\mathrm{Ab}$ initio calculations (using density functional theory, DFT) suggest that (i) $[4 \mathrm{H}]_{\mathrm{Si}}$ is energetically the most favourable intrinsic defect species (Purton et al., 1992; McConnell et al., 1995; Rosa et al., 2005), which (ii) converts to molecular water during the development of dislocations (McConnell et al., 1995), and (iii) that the Griggs defect is unstable in unstrained quartz (Purton et al., 1992).

\section{Influence of $\mathrm{OH}$ point defects on physical properties}

The incorporation of $\mathrm{OH}$ species influences the physical properties in different ways: (1) the high mobility of protons enhance the electrical conductivity by acting as charge carrier, and (2) protons modify the chemical bonds and thereby the mechanical properties of the silica network itself. The electrical conductivity depends on the concentration and mobility of mobile species and can be described by the Nernst-

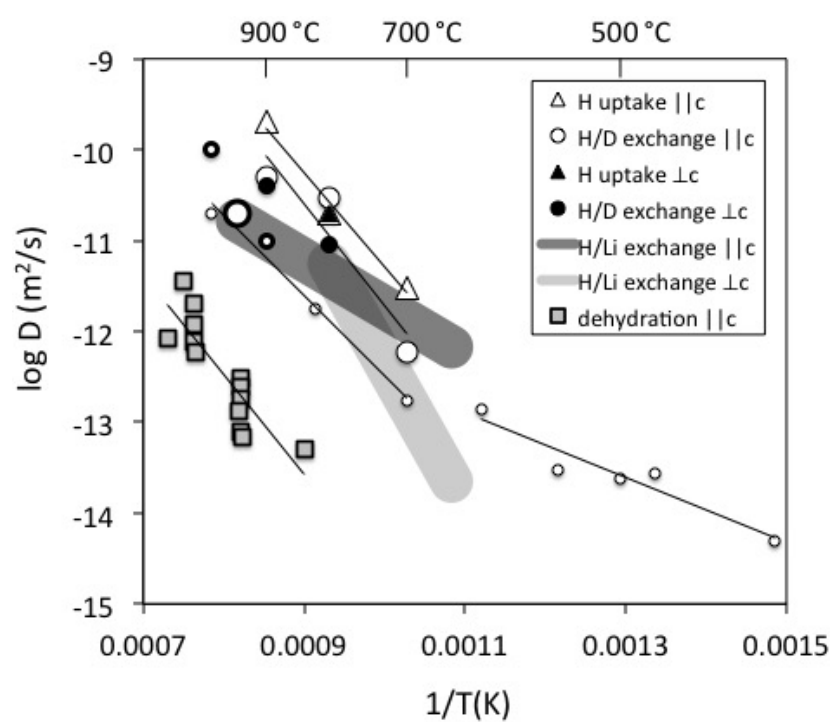

Figure 2. Diffusivities of $\mathrm{H}$ determined on natural quartz crystals. Data are derived from Brunner et al. (1961) - open large thick circle, Kats (1962) - open small thin circles, Rovetta et al. (1986) - open small thick circle, Kronenberg et al. (1986) - open large thin circles and triangles and filled circles and triangle, Bachheimer (1998) grey squares, Jollands et al. (2020b) - dark grey field, and Stalder (unpublished data) - light grey field. Method and diffusion direction are given in the legend.

Einstein equation:

$\sigma=\frac{\sum_{i}\left(D_{i} c_{i} z_{i}^{2}\right)}{k_{\mathrm{B}} T}$,

where $\sigma$ is the bulk electrical conductivity, $k_{\mathrm{B}}$ is the Boltzmann constant, $T$ is the absolute temperature, and $D_{i}, c_{i}$, and $z_{i}$ are the diffusion coefficients, the concentration, and the charge, respectively, of the mobile species $i$. In quartz, the principle charge carriers are protons and thus crucial for long-term DC (direct current) conductivity (Kronenberg and Kirby, 1987). In order to calculate the electrical conductivity according to Eq. (4), the diffusivities of protons from different $\mathrm{OH}$ species ( $\mathrm{H}$ not linked to $\mathrm{Al}$, and $\mathrm{H}$ linked to $\mathrm{Al}$ ) have to be known.

A number of different strategies to determine $\mathrm{H}$ diffusivities have been followed, such as hydrogen uptake (Shaffer et al., 1974; Kronenberg et al., 1986), hydrogen extraction (Bachheimer, 1998), H/D exchange (Brunner et al., 1961; Kats, 1962; Rovetta et al., 1986), and H/Li exchange (Jollands et al., 2020b). All methods represent different processes with different rate-limited steps. In addition, diffusion experiments were performed with different starting materials (although mostly with natural hydrothermal rock crystals with $\mathrm{AlOH}>\mathrm{LiOH}$ ). Consequently, they reflect different diffusion mechanisms, and the results spread by several log units at a given temperature (Fig. 2): the H/D inter-diffusion coefficient is a good approximation for the self-diffusion of 
$\mathrm{H}$; in contrast, $\mathrm{H}$ uptake or extraction can be rate-limited by other diffusivities depending on the charge balance it is based on and may in fact be slower by orders of magnitude. The hitherto reported H/D exchange experiments above $700^{\circ} \mathrm{C}$ all fall into a narrow range (Fig. 2) and exhibit a rather high activation energy around $200 \mathrm{~kJ} / \mathrm{mol}$. Experiments at lower temperatures reveal a marked drop in the activation energy to approximately $70 \mathrm{~kJ} / \mathrm{mol}$ (Kats, 1962). This remarkable change has been interpreted as the transition between two regimes, in which the diffusing species is dominated by $\mathrm{H}$ not linked to $\mathrm{Al}$ at low temperatures in contrast to the results at high temperatures, in which $\mathrm{H}$ is predominantly linked to $\mathrm{Al}$ (Kronenberg and Kirby, 1987). H uptake experiments by Kronenberg et al. (1986) show a similar diffusion law as H/D exchange until the charge neutrality $[\mathrm{Al}]=[\mathrm{H}]$ is reached, which suggests that the diffusion probably relies on a similar mechanism to $\mathrm{H} / \mathrm{D}$ exchange. IR spectra revealed a defect ratio $\mathrm{AlOH}>\mathrm{LiOH}$ at the beginning of the experiment, and $\mathrm{AlOH}>>\mathrm{LiOH}$ (with nearly no $\mathrm{LiOH}$ ) at the end of the experiments. This finding insinuates that to some extent $\mathrm{H} / \mathrm{Li}$ exchange (and $\mathrm{H}$ exchange with other alkalis) occurred, but the majority of the protons incorporated during the experiment has to combine with the existing $\mathrm{Al}_{\mathrm{Si}}^{\prime}$ defects (a dry defect, in which $\mathrm{Al}$ is on a tetrahedral position and exhibits a local charge deficit) to an $\mathrm{AlOH}$ defect. It is furthermore noteworthy that initial samples used for $\mathrm{H}$ extraction (Bachheimer, 1998) reveal IR absorption spectra that are similar to the hydrated sample of Kronenberg et al. (1986), but H extraction still does not seem to follow the reverse process of $\mathrm{H}$ uptake. Some of the differences between these two studies may partly be explained by missing exchange options by alkalis in the extraction experiments. Interestingly, the activation energies are similar, but diffusivities for $\mathrm{H}$ extraction are shifted towards lower values by 3 log units (compare $\mathrm{H}$ uptake and dehydration in Fig. 2). For crystals without other defects than those that follow the charge neutrality $[\mathrm{Al}]=[\mathrm{H}]$, a lower diffusivity for $\mathrm{H}$ extraction than from self-diffusion is expected since another - negatively charged - species is involved. A possible candidate for this negatively charged species is oxygen, which is several orders of magnitude slower. Other explanations for the discrepancies between $\mathrm{H}$ uptake and dehydration are the redox behaviour of trace amounts of $\mathrm{Fe}$ (not reported in these studies) or preexisting other defects.

For the $\mathrm{H} / \mathrm{Li}$ exchange process in quartz a lower activation energy of $100 \mathrm{~kJ} / \mathrm{mol}$ was recently determined (Jollands et al., 2020b), which is rather similar to the low temperature H/D exchange data of Kats (1962) and in accordance with the interpretation that the diffusing $\mathrm{H}$ species is not linked to $\mathrm{Al}$ (Kronenberg and Kirby, 1987). H/Li exchange is influenced by the Li mobility. Estimates for Li diffusion in quartz yield similar to slightly higher values than for $\mathrm{H}$ (Charlier et al., 2012). Considering the inter-diffusivity,

$D_{\mathrm{H}-\mathrm{Li}}=\frac{\left(X_{\mathrm{H}}+X_{\mathrm{Li}}\right) D_{\mathrm{H}} D_{\mathrm{Li}}}{X_{\mathrm{H}} D_{\mathrm{H}}+X_{\mathrm{Li}} D_{\mathrm{Li}}}$

with $D=$ diffusivity and $X=$ mole fraction, the mismatch between the observed $\mathrm{H}$ mobility in $\mathrm{H} / \mathrm{Li}$ exchange $\| c$ (Jollands et al., 2020b) and $\mathrm{H} / \mathrm{D}$ exchange experiments $<600^{\circ} \mathrm{C}$ IIc (Kats, 1962) by up to a factor of 3 (half a log unit) may be explained (Fig. 2). Taking into account that the samples from both studies differed strongly with respect to absolute $\mathrm{H}$ and $\mathrm{Li}$ content, diffusion can be considered concentration independent and $D_{\mathrm{H}}$ and $D_{\mathrm{Li}}$ very similar.

No significant dependence of $\mathrm{H}$ mobility on pressure (Kronenberg et al., 1986) and oxygen fugacity (Jollands et al., 2020b) was observed. Similarly, no pronounced anisotropy (difference between diffusivity $\| c$ and $\perp c$ ) was found for $\mathrm{H}$ uptake and H/D exchange (Kronenberg et al., 1986) and H extraction (Bachheimer, 1998); the effect for $\mathrm{H} / \mathrm{Li}$ exchange was not quantified with regard to crystal orientation in these studies, but a slower diffusivity for diffusion $\perp c$ than $\| c$ was reported (Jollands et al., 2020b).

The presence of defect protons has an indirect impact on other physical properties. In this context it has been shown that the incorporation of protons enhance the diffusivity of $\mathrm{O}$ within the crystal lattice and thus indirectly influence the mechanical properties of quartz (Elphick and Graham, 1988). After the first observation of hydrolytic weakening of quartz (Griggs and Blacic, 1965; Griggs et al., 1966), the nature of the relevant $\mathrm{OH}$ species assumed to facilitate the deformation was extensively debated. The discussion primarily concentrated on intrinsic defects such as $\mathrm{SiOH}$, while $\mathrm{AlOH}$ as a chemically very stable defect was not considered as a relevant species for hydrolytic weakening (Cordier and Doukhan, 1991). The initial model assumed that weakening was caused by the formation of Griggs-type defects by the following reaction (Griggs et al., 1966; Aines et al., 1984):

$\mathrm{Si}-\mathrm{O}-\mathrm{Si}+\mathrm{H}_{2} \mathrm{O}=\mathrm{Si}-\mathrm{OH}$ HO-Si.

Later on it was suggested that actually hydrogarnet defects $[4 \mathrm{H}]_{\mathrm{Si}}$ are the relevant species that help activating dislocations and thus facilitate hydrolytic weakening (Doukhan and Trépied, 1985; Cordier et al., 1994). Based on the observation of the precipitation of molecular water bubbles during the formation of dislocations (Cordier et al., 1988; Cordier and Doukhan, 1991), a conversion of hydrogarnet defects to molecular water during dislocation (according to Eq. 4) was suggested (McConnell et al., 1995). A transformation between different $\mathrm{OH}$ species was also observed during the thermal annealing of previously deformed quartz, in which recrystallised samples contained less molecular water due to the conversion into point defects (Niimi et al., 1999). 


\section{$9 \mathrm{OH}$ incorporation in quartz in experimental petrology}

It has been shown early by hydrothermal annealing at $15 \mathrm{kbar}$ and $900^{\circ} \mathrm{C}$ (Mackwell and Paterson, 1985; Rovetta, 1989) that quartz is able to incorporate high amounts of $\mathrm{OH}$ (up to $150 \mathrm{wt} \mathrm{ppm}$ water) and, furthermore, that $\mathrm{OH}$ incorporation is enhanced at low oxygen fugacities (Rovetta, 1989). The interpretation of incorporation as point defects was soon challenged, and it has been argued that $\mathrm{OH}$ is mainly hosted in fluid inclusion (Gerretsen et al., 1989). Experimental research activities in the following years were focussed on the role of $\mathrm{OH}$ during deformation of quartz and studying $\mathrm{OH}$ in other nominally anhydrous minerals, and relevant data from experimental petrological studies on $\mathrm{OH}$ in quartz, which were applicable to granitic systems, were not published until the beginning of the past decade. By using a new analytical protocol (Stalder and Konzett, 2012), the isotropic contribution of molecular water (and species in melts and other amorphous material) could be erased from the IR absorption spectrum, and the contribution from $\mathrm{OH}$ point defects could be determined even in sub-millimetres, inclusion-rich crystals from high-pressure experiments.

Synthesis experiments in simple systems allow for the assignment of $\mathrm{OH}$ bands to metal impurities by investigating pure systems and systems doped with the respective metal ions. This allowed us to verify the nature of intrinsic defects (in the following referred to as hydrogarnet) and impurityspecific defects in particular, and the substantial influence of $\mathrm{B}$ on $\mathrm{OH}$ incorporation was shown (Fig. 1).

Quartz from high-pressure experiments in granitic systems exhibit $\mathrm{OH}$ defect contents between 30 and $600 \mathrm{wt}$ ppm water, depending on the pressure and composition of the system (Fig. 3). The influence of crystallisation temperature is not very well constrained because melt viscosities and the $\mathrm{P}-\mathrm{T}$ circumstances in the phase diagrams for realistic scenarios set rather narrow limits for successful experiments which are expected to provide sufficiently large quartz crystals for further analysis. However, no clear temperature trend on $\mathrm{OH}$ incorporation was established in a haplogranitic system (Stalder and Konzett, 2012). Between 1 and 5 kbar, pressure seems to have a rather small systematic influence (Potrafke et al., 2019), except for a narrow region at 4 to $4.5 \mathrm{kbar}$ close to the high/low quartz transition in which a sudden increase in $\mathrm{OH}$ and metal impurities was observed. Between 5 and $25 \mathrm{kbar}$, a negative pressure trend (Fig. 3) was observed in each studied system (Stalder and Konzett, 2012; Baron et al., 2015; Frigo et al., 2016), leading to the suggestion that the most pure quartz (inclusive of the charge-balancing metal ions) is formed at the quartz/coesite transition (Frigo et al., 2019). IR spectra recorded on quartz from high-pressure syntheses in granitic systems are usually dominated by the $\mathrm{AlOH}$ triplet (Fig. 1c). If the system is saturated with tourmaline (Baron et al., 2015) and/or Li (Frigo et al., 2016; Potrafke et al., 2019), specific $\mathrm{BOH}$ and $\mathrm{LiOH}$ are observed in

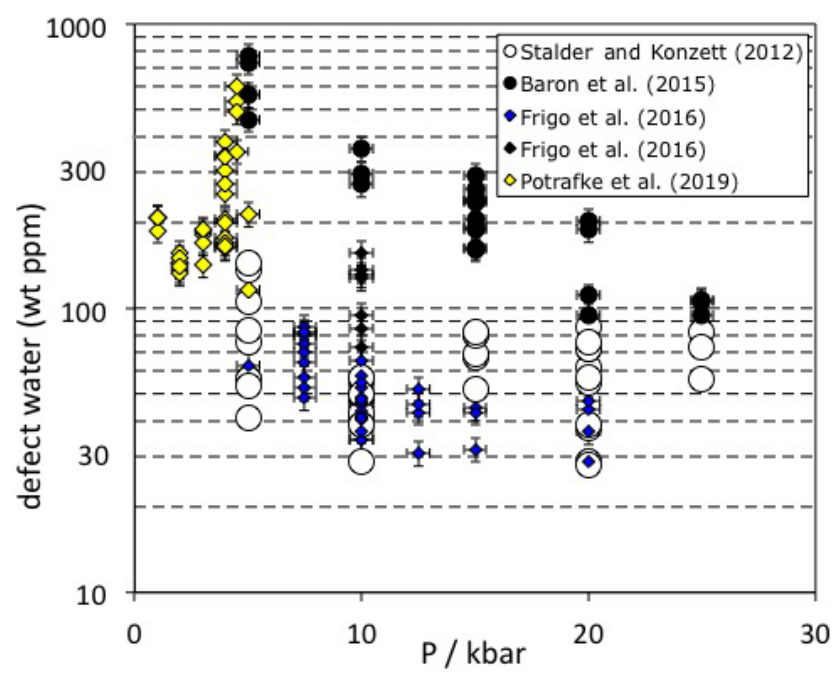

Figure 3. Pressure dependence of $\mathrm{OH}$ incorporation in quartz. Data are from experimental studies in granitic and haplogranitic systems with final run temperatures between 800 and $900^{\circ} \mathrm{C}$. Each data point represents one measured oriented crystal. Experiments from Baron et al. (2015) were doped with tourmaline and Frigo et al. (2016) with spodumene (blue symbols) or tourmaline (black symbols).

addition. More detailed studies (Stalder and Konzett, 2012; Baron et al., 2015) observed a negative pressure trend for $\mathrm{AlOH}$ that may be explained by the unfavourable size of $\mathrm{Al}^{3+}$ in the tetrahedral site at high pressure (Potrafke et al., 2019). Furthermore, $\mathrm{LiOH}$ is strongly decreased with pressure especially around the high/low quartz transition (Frigo et al., 2016), while BOH does not show a clear pressure trend (Baron et al., 2015). These observed trends lead to the situation that at low pressure the linear absorbance of the $\mathrm{LiOH}$ band may nearly reach the absorbance of the $\mathrm{AlOH}$ main band (Potrafke et al., 2019), and at high pressure the $\mathrm{BOH}$ band may even exceed the linear absorbance of the main $\mathrm{AlOH}$ band in some cases (Baron et al., 2015). The hydrogarnet defect shows a positive pressure dependence, possibly culminating in a maximum at 20-25 kbar (Stalder and Konzett, 2012), but it never reaches the absorbance of the $\mathrm{AlOH}$ band in granitic systems.

\section{$10 \mathrm{OH}$ in natural quartz from different origin}

In contrast to experimentally grown quartz from granitic systems (Baron et al., 2015; Frigo et al., 2016; Potrafke et al., 2019) in which high $\mathrm{OH}$ defect contents ranging between $30 \mathrm{wt} \mathrm{ppm}$ and $600 \mathrm{wt} \mathrm{ppm}$ water were observed (Fig. 3), natural quartz from granitic and hydrothermal systems show large variation and median values around $20 \mathrm{ppm}$ water (Table 1). Average crustal quartz represented by siliciclastic sediments hosts only $10 \mathrm{wt}$ ppm water as $\mathrm{OH}$ defects (Stalder, 2014), while metamorphic and volcanic sam- 
ples cluster around 5 wt ppm (Table 1). The large discrepancy between natural and experimentally grown quartz from water-saturated systems may have several reasons, such as (1) reduced water activity during crystallisation in natural systems leading to reduced $\mathrm{OH}$ incorporation (Stalder and Konzett, 2012) and (2) metamorphic overprint leading to partial or total OH loss (Stalder et al., 2017). In accordance with the high-pressure experiments, the highest reported values in natural quartz closely reach values above $200 \mathrm{wt}$ ppm water (Bambauer et al., 1962), and even in the sedimentary archives a handful of grains with $\mathrm{OH}$ defect contents $>100 \mathrm{ppm}$ water are preserved (Stalder, 2014; Jaeger et al., 2019, see Table 1). Interestingly, most of the $\mathrm{OH}$-rich grains from sediments that retained a high $\mathrm{OH}$ defect content are dominated by $\mathrm{AlOH}$ defects, which is in contrast to the late-stage igneous samples with high $\mathrm{OH}$ contents (Fig. 1d). Possibly, these grains underwent very low-grade thermal treatment after formation (and before sedimentation) that led to a transformation of the $\mathrm{LiOH}$ to $\mathrm{AlOH}$ absorption bands, comparable to thermal annealing experiments on quartz (Brunner et al., 1961; Rovetta et al., 1986; Stalder et al., 2017).

\subsection{Granites and granitic pegmatites}

$\mathrm{OH}$ contents in quartz from hitherto analysed granites vary between $0 \mathrm{wt} \mathrm{ppm}$ and $72 \mathrm{wt} \mathrm{ppm}$ water (Table 1) with a median value around $3 \mathrm{wt} \mathrm{ppm}$ for Proterozoic samples from Scandinavia with ages around $1.8 \mathrm{Ga}$ and median values around 20-35 wt ppm for Variscan samples with ages around 0.3 Ga (Stalder et al., 2017; Potrafke et al., 2020). Neoproterozoic samples (ages around $0.9 \mathrm{Ga}$ ), and some samples from the Paleoproterozoic Transscandinavian Igneous Belt, may reach 10-20 wt ppm (Müller and Koch-Müller, 2009; Stalder et al., 2017). The observed differences may either reflect (i) primary igneous incorporation, (ii) secondary processes such as dehydration, or (iii) a combination of both. Specifically, the observed differences could be explained by the different crustal levels that were sampled (having in mind the experimentally determined pressure trend) or by a longterm low-grade metamorphic overprint that caused a partial dehydration. In this context it is interesting that older sedimentary archives from Scandinavia (such as the $1.4 \mathrm{Gyr}$ old Dalarna subarkose sandstone) reveal information about the upper portion of the same Paleoproterozoic source that is exposed today. During the sedimentation of the Dalarna sandstone (1.4 Gyr ago), the igneous rocks had a similar age as Variscan samples have today, and a significant fraction of very OH-rich grains was preserved (Stalder, 2014). The interpretation of the long-term low-grade overprint is supported by the observations that IR spectra of quartz from old granitic bodies are typically dominated by $\mathrm{AlOH}$ absorption bands, the thermally less stable $\mathrm{LiOH}$ band is not observed, and there is a tendency of higher $\mathrm{OH}$ contents towards the centre of the body (Stalder et al., 2017). Variscan granites are dominated by $\mathrm{AlOH}$, too, but in contrast often exhibit strong
LiOH bands (Stalder et al., 2017; Potrafke et al., 2020) even if they are subordinate or missing in some cases (Müller et al., 2009).

In order to better understand the systematics of $\mathrm{OH}$ incorporation in quartz during igneous rock formation, several granitic bodies were investigated in more detail. For the Variscan samples from the Black Forest, spectral characteristics show an array with a negative correlation of $\mathrm{LiOH}$ versus total OH (Stalder et al., 2017). A similar trend is observed for the Zinnwald samples (a modally zinnwaldite-bearing granite) in their dependence on depth, with moderate $\mathrm{LiOH}$ and high total $\mathrm{OH}$ at low depth, followed by a decrease in total $\mathrm{OH}$ and an increase in $\mathrm{LiOH}$ towards greater depth (Fig. 4). A different trend with increasing depth is observed for the Podlesí stock granite, in which low $\mathrm{LiOH}$ and moderate total $\mathrm{OH}$ contents are followed by an increase in $\mathrm{LiOH}$ and subsequently a decrease in $\mathrm{LiOH}$ and an increase in total $\mathrm{OH}$ (Fig. 4). Due to the rather small depth interval, the pressure effect can probably be neglected. The process behind the $\mathrm{OH}$ defect variations is possibly controlled by the activity of $\mathrm{Li}$ and water in the system similar to experimentally determined trends, in which more Li in the system causes a shift towards higher $\mathrm{LiOH}$ and lower total $\mathrm{OH}$ due to the formation of dry AlLi defects (Frigo et al., 2016), and a reduced water activity generally leads to lower total $\mathrm{OH}$ contents (Stalder and Konzett, 2012).

Reported $\mathrm{OH}$ contents for quartz from granitic pegmatites (Table 1) cluster around $20 \mathrm{wt}$ ppm water with a range between $6 \mathrm{wt}$ ppm and $45 \mathrm{wt}$ ppm (Müller and Koch-Müller, 2009). One pegmatitic comb quartz from the granite stock in Podlesí, Czech Republic (Breiter et al., 2005), revealed an $\mathrm{OH}$ content of $132 \mathrm{wt}$ ppm (Fig. 1d, Table 1).

\subsection{Rhyolitic tuffs and ignimbrites}

$\mathrm{OH}$ contents in quartz from felsic volcanic rocks up to $13 \mathrm{wt} \mathrm{ppm}$ water and average values of $6 \mathrm{wt} \mathrm{ppm}$ were reported from different studies (Table 1). IR absorption spectra of all studies reveal nearly exclusively $\mathrm{AlOH}$ defects (Müller et al., 2009; Stalder and Neuser, 2013; Biró et al., 2016, 2017; Tollan et al., 2019), and a clear intra-crystalline zoning pattern was observed with decreasing $\mathrm{Al}$ and $\mathrm{OH}$ contents from core to rim (Tollan et al., 2019). In accordance with the charge balance equation established above (Eq. 1), protons are charge balanced by $\mathrm{Al}^{3+}$ and are in concurrence with alkali cations. Diffusive $\mathrm{H} / \mathrm{Li}$ exchange at the rim can lead to a further decrease in $\mathrm{OH}$ as observed in quartz phenocrysts from Mesa Falls Tuff, Idaho (Tollan et al., 2019), and from Bishop Tuff, California (Jollands et al., 2020b). A pronounced decrease from the base towards the middle part of thick pyroclastic density current deposits in the Bükk Foreland volcanic area, Hungary, was observed, which was explained by diffusional loss after deposition and slow cooling (Biró et al., 2017). After all, it seems to be clear that the observed differences between crystals from the same erup- 


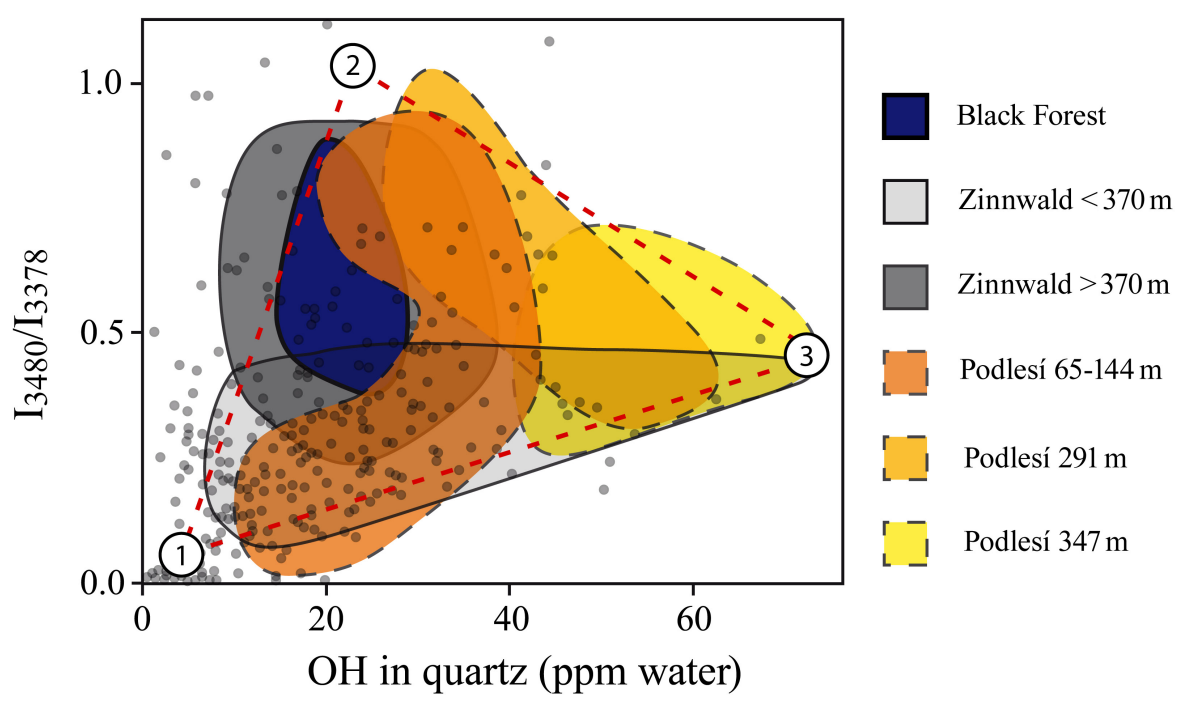

Figure 4. Spectral characteristic (ratio of the linear absorbances $I_{3480} / I_{3378}$, representing the ratio LiOH/AlOH) plotted against absolute $\mathrm{OH}$ content for quartz from river samples from the Elbe and Rhine (grey solid dots) compared to quartz from Variscan plutons (coloured fields; see legend). Sediment data are derived from Stalder et al. (2017, 2019), granite data for the Black Forest samples from Stalder et al. (2017), and for Podlesí and Zinnwald from Potrafke et al. (2020). Numbers refer to the components defined in the text.

tion cannot be explained by processes in the magma chamber but rather reflect a snapshot of ongoing late-stage modifications of the $\mathrm{OH}$ defect inventory that can be quantified in terms of diffusional loss and allows for an estimate on the timescales of long-lasting cooling.

\subsection{Hydrothermal quartz}

Hydrothermal quartz specimens have been investigated for decades, and the range of $\mathrm{OH}$ contents is rather large $(0$ 225 wt ppm water; Table 1); individual crystals reveal strong internal zoning (Chakraborty and Lehmann, 1976a) with respect to $\mathrm{OH}$ and vary even between zero and high defect contents ( $>20 \mathrm{wt}$ ppm water) within one specimen (Stalder et al., 2017). In contrast to quartz from most other formation processes (notably except pegmatites), hydrothermal quartz often exhibits strong $\mathrm{LiOH}$ absorption bands (Brunner et al., 1961; Chakraborty and Lehmann, 1976b; Müller and KochMüller, 2009) that may match or even exceed the intensity of AlOH bands (Yurimoto et al., 1989; Stalder and Neuser, 2013). An increasing $\mathrm{LiOH} / \mathrm{AlOH}$ defect ratio shows a positive correlation to the total $\mathrm{OH}$ content (Bambauer et al., 1963 ) and reaches values around unity for the most $\mathrm{OH}$-rich specimens.

Different populations of hydrothermal quartz have been distinguished (Bambauer, 1961): (1) "usual" hydrothermal quartz with moderate $\mathrm{OH}$ defect contents with up to $8 \mathrm{wt}$ ppm water and (2) mimetic quartz with $\mathrm{OH}$ defect contents corresponding to up to $180 \mathrm{wt}$ ppm water. Common colourless rock crystals often have a few weight parts per million water as $\mathrm{OH}$ defects (Table 1), while smoky quartz on average even contains $\mathrm{OH}$ contents which are lower by a factor of 2 to 10 (Brunner et al., 1961; Bambauer, 1961; Bambauer et al., 1962). Higher OH contents (comparable to values of rock crystals) are observed in weakly coloured smoky quartz and their colourless cores (Bambauer et al., 1962).

The areal distribution of $\mathrm{OH}$ in fissure quartz of the central Alps (Bambauer et al., 1962) revealed a regional pattern depending on formation conditions, locally superimposed by the country rock and fluid chemistry. In detail, a correlation between the $\mathrm{OH}$ contents of fissure quartz and the metamorphic grade in the regional context could be established (Fig. 5), in which feldspar compositions towards more Narich (up to $A b_{17}$ ) adularia and anorthite-rich plagioclase in metacarbonates (representing high temperature) accompany quartz with high $\mathrm{OH}$ content, and Na-poor adularia and albite (representing low temperature) were found in fissures containing quartz with low $\mathrm{OH}$ contents. Even if it was pointed out (Bambauer et al., 1962) that fissure quartz is formed under different conditions (not only at peak metamorphism), higher metamorphic temperature implies an earlier start of crystallisation in which the fluid phase was more enriched in the charge-balancing trace metals that finally lead to the increased incorporation of $\mathrm{OH}$ defects.

\subsection{Metamorphic rocks}

$\mathrm{OH}$ defect contents in quartz from metamorphic rocks are generally low $(<5 \mathrm{wt} p \mathrm{pm}$ water) and seldom exceed $10 \mathrm{wt} \mathrm{ppm} \mathrm{water} \mathrm{(Table} \mathrm{1).} \mathrm{IR} \mathrm{spectra} \mathrm{are} \mathrm{generally} \mathrm{strongly}$ dominated by the $\mathrm{AlOH}$ triplet (Müller and Koch-Müller, 2009; Stalder et al., 2017) in accordance with the observed limited thermal stability of $\mathrm{LiOH}$. Thus, low $\mathrm{LiOH} / \mathrm{AlOH}$ combined with low total $\mathrm{OH}$ is typical - although not un- 


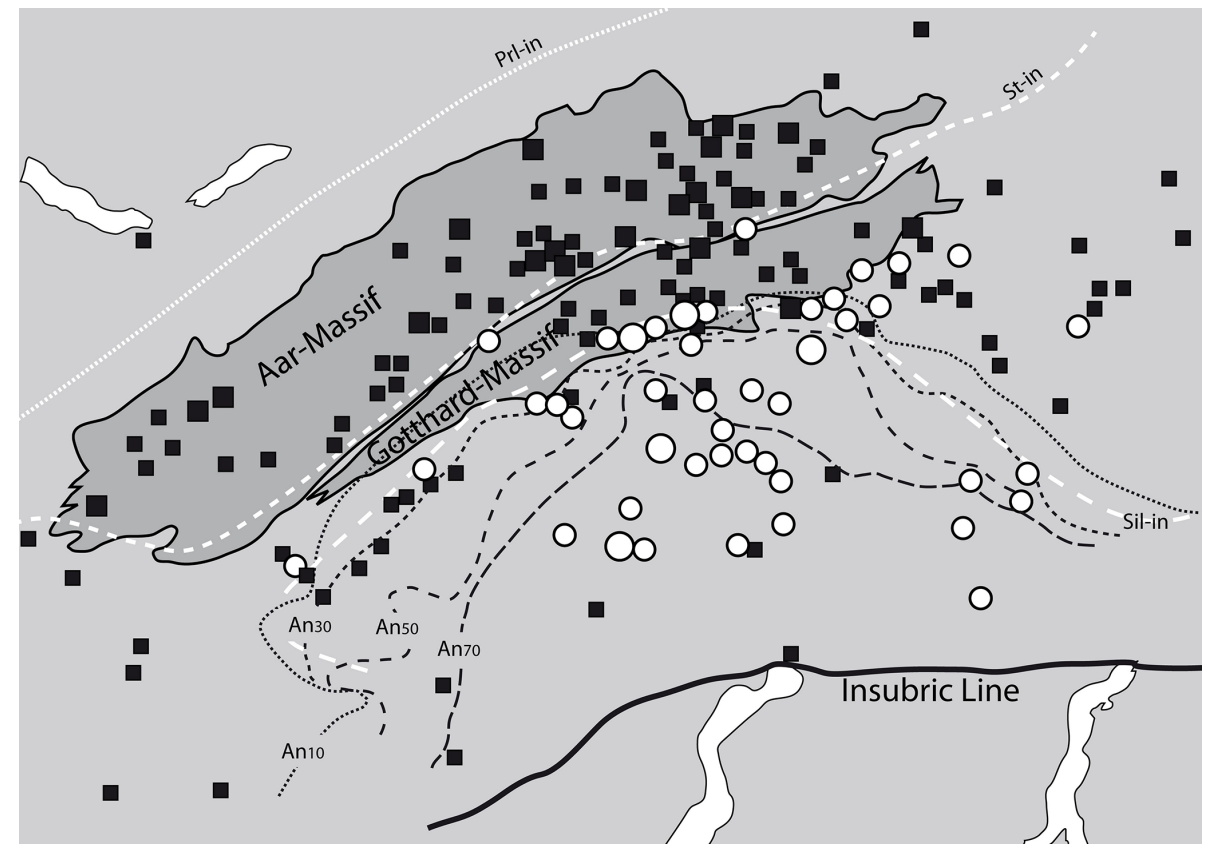

Figure 5. Correlation of $\mathrm{OH}-$ poor and $\mathrm{OH}$-rich fissure quartz (data from Bambauer et al., 1962) to metamorphic isograds (plagioclase composition - Wenk, 1962; isograds in metapelites - Frey and Ferreiro-Mählmann, 1999). Prl: pyrophyllite; St: staurolite; Sil: sillimanite; An: anorthite. Solid squares represent $\mathrm{OH}$-poor $(<2 \mathrm{wt}$ ppm water) and open circles $\mathrm{OH}-\mathrm{rich}(>4 \mathrm{wt}$ ppm water) common fissure quartz. Large symbols summarise several samples from nearby localities.

equivocally diagnostic - for metamorphic quartz. In contrast to $\mathrm{LiOH}$, but in accordance with a high thermal stability of $\mathrm{BOH}$, the absorption band at $3595 \mathrm{~cm}^{-1}$ was detected in quartz grains from a tourmaline-bearing Qz eclogite (Stalder and Neuser, 2013). A systematic study on quartzites from Norway (Müller and Koch-Müller, 2009) suggests a rough tendency towards higher $\mathrm{OH}$ contents for quartz from kyanite-bearing quartzites ( $9 \mathrm{wt} \mathrm{ppm}$ ) compared to kyanitefree quartzites $(6 \mathrm{wt} p \mathrm{pm})$. It is not clear whether this putative difference is caused by pressure and/or availability of $\mathrm{Al}$ (both properties ascribed to the presence of kyanite). Pressure is probably not an important factor because there is no systematic difference in the equilibration pressure of the studied kyanite-bearing and kyanite-free quartzites, and, furthermore, a pressure trend is not expected with respect to the experimental results. The availability of $\mathrm{Al}$ is not a very probable explanation either because the $\mathrm{AlOH}$ defect is dominant in all quartzites and $\mathrm{Al}$ diffusion is much too slow (around $10^{-22} \mathrm{~m}^{2} / \mathrm{s}$ at $600^{\circ} \mathrm{C}$; Tailby et al., 2018) to account for incorporation of new $\mathrm{AlOH}$ defects at metamorphic conditions. Based on the present data set it is not clear whether the difference between kyanite-bearing and kyanite-free samples is significant at all. A clear temperature trend has not been established, at least not for the kyanitefree quartzites (Fig. 6). Information concerning the equilibration temperature in quartz-rich metasediments may be gained from the distribution of $\mathrm{OH}$ between different grains. While a homogeneous defect distribution was observed in a quartzite from Hohe Tauern, Austria, that was metamorphosed at $600^{\circ} \mathrm{C}$ (Stalder et al., 2017), quartzites from Vredefort, South Africa, with a metamorphic overprint at $350^{\circ} \mathrm{C}$ revealed strongly different $\mathrm{OH}$ contents from grain to grain, suggesting that at low temperatures the originally variable sedimentary $\mathrm{OH}$ content of the individual grains may (partly) be preserved. The influence of deformation has not been assessed in detail yet. In particular, the presence of $\mathrm{OH}$ may not only be crucial for hydrolytic weakening, but in turn, deformation probably also promotes the equilibration of $\mathrm{OH}$ defects.

\subsection{Siliciclastic sediments}

Most quartz crystals in the Earth originally crystallised in felsic igneous bodies that comprise about half of the volume of the continental crust (Wedepohl, 1995) and - due to their low density - sooner or later are uplifted, exposed, eroded, and transported into sedimentary basins where they are mixed with other sources from metamorphic rocks and/or recycled sediments. Finally, a sedimentary quartz grain either retained its original igneous $\mathrm{OH}$ signature or experienced a decrease in $\mathrm{LiOH} / \mathrm{AlOH}$ by mild thermal treatment or additionally a strong decrease in total $\mathrm{OH}$ by more intense thermal treatment. Consequently, variations in spectral characteristics of sedimentary quartz show a fair overlap to their igneous source rocks (Fig. 4) supplemented by a variable amount of low $\mathrm{OH}$ grains from metamorphic sources. Re- 


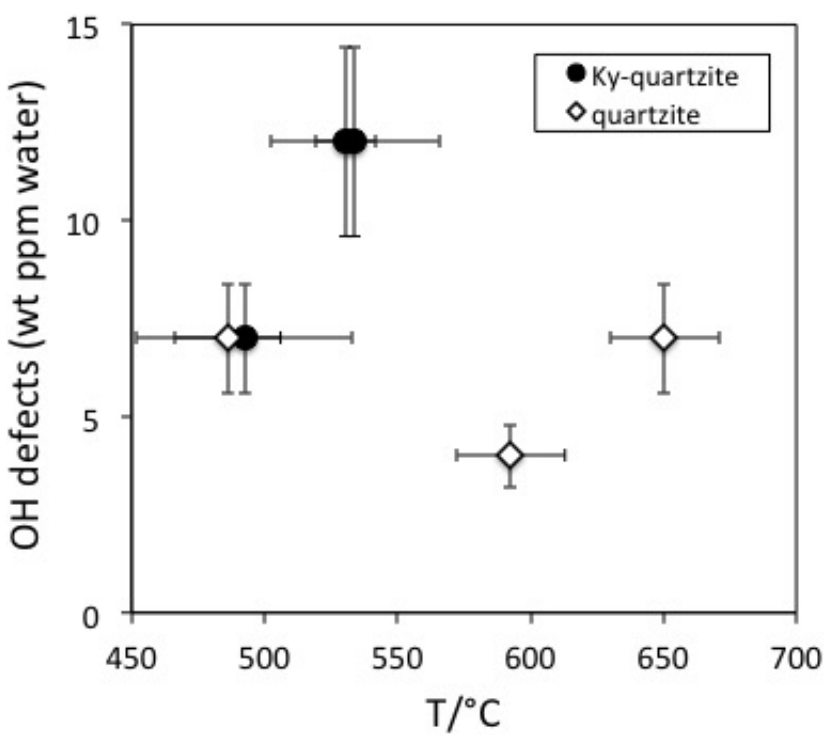

Figure 6. $\mathrm{OH}$ defect contents in quartzites from Norway. Data are from Müller and Koch-Müller (2009).

markably, most data points fall within an array that can be defined as a triangle (similar to the one defined by the quartz crystals from granites) with the edges at (1) low $\mathrm{OH}$ content and low $\mathrm{LiOH} / \mathrm{AlOH}$, (2) moderate $\mathrm{OH}$ contents and high $\mathrm{LiOH} / \mathrm{AlOH}$, and (3) high $\mathrm{OH}$ contents and moderate $\mathrm{LiOH} / \mathrm{AlOH}$. Siliciclastic sediments therefore provide a wealth of information of eroded parts of felsic plutons. Furthermore, they serve as good proxy for average crustal quartz (Stalder, 2014).

Average spectra from large sedimentary reservoirs are dominated by grains with absorption bands derived from AlOH defects (Stalder and Neuser, 2013; Stalder, 2014), but average spectra of more local sources and of individual grains may exhibit strong $\mathrm{BOH}$ and/or $\mathrm{LiOH}$ (Stalder et al., 2017). OH contents in quartz from sedimentary systems hitherto investigated exhibit a wide variability (Fig. 7) and average $\mathrm{OH}$ concentrations in quartz sands vary even within Central Europe by a factor of 5, ranging from $4 \mathrm{wt} \mathrm{ppm}$ water for a beach sand from the Baltic Sea to more than $20 \mathrm{wt}$ ppm water in a river sand from the Rhine (Stalder et al., 2017). Estimations based on large siliciclastic reservoirs suggest that $50 \%$ of all quartz grains contain $>5 \mathrm{wt}$ ppm water on average globally (Fig. 7). River sediments exhibit a large spread, and in Central Europe there is a general tendency of high $\mathrm{OH}$ contents (plotting to the right in Fig. 7) towards the south and west (e.g. the Rhine) and low $\mathrm{OH}$ contents towards the north (e.g. Baltic Sea, North Sea, and northern Elbe). Taking into account the main transport directions from north to south during the quaternary glaciations and from south to north for the recent main river systems (Rhine and Elbe) and during the erosion of the Variscan Mountains in the Mesozoic, a clear correlation to the $\mathrm{OH}$ content of the granites in the

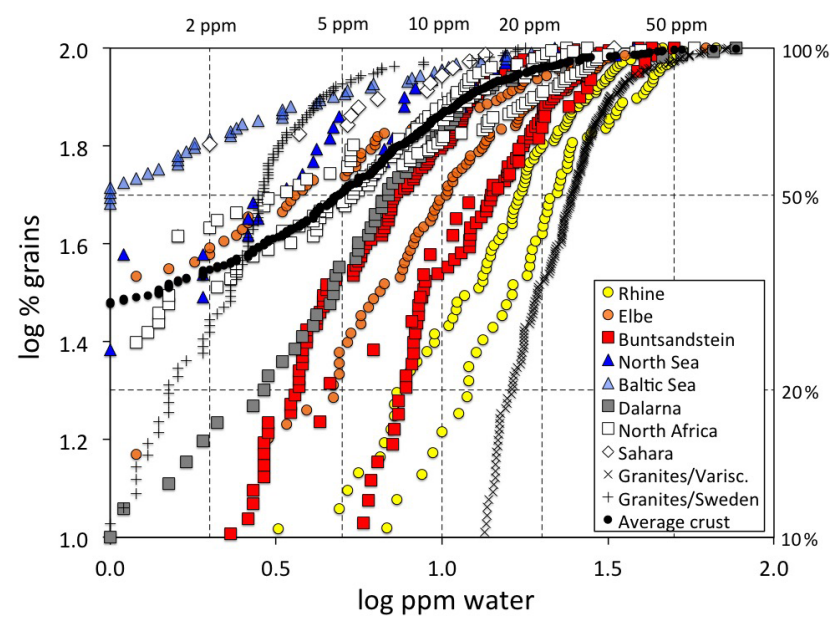

Figure 7. $\mathrm{OH}$ defect distribution of quartz grains from sedimentary samples (squares: sandstones; circles: river sediments; triangles: beach/dune sands). The right hand $y$ axis gives the percentage of grains below the respective defect water content. Data points below $1 \mathrm{wt}$ ppm water are not plotted due to the large uncertainty. Data for the sedimentary samples are derived from Stalder and Neuser (2013) for the North Sea and Buntsandstein; Stalder (2014) for Dalarna, North Africa, Sahara, and average crust; Stalder et al. (2017) for the Rhine and Baltic Sea; and Stalder et al. (2019) for the Elbe, Buntsandstein, and North Africa. Data for European granites (Proterozoic from Sweden and Variscan from Central Europe are shown for comparison and are derived from Stalder et al. (2017) and Potrafke et al. (2020). For some systems (Rhine, Elbe, Buntsandstein, North Sea, North Africa) several samples are plotted with the same symbol (see text for further details).

source regions emerges (Fig. 8), linking samples with predominantly $\mathrm{OH}$-poor quartz to old sources (in this case the Proterozoic Scandinavian Shield) and $\mathrm{OH}$-rich quartz samples to much younger (in this case late Palaeozoic) sources. Due to this clear contrast, $\mathrm{OH}$ defects in quartz can even be used to estimate mixing relations of fluvial sources (from the Variscan basement) and glacial sources (from Scandinavia, also called "Nordic signal") in Central Europe. In sediments from the northern Elbe a significant fraction shows $\mathrm{OH}$ defect contents in quartz $>10 \mathrm{wt}$ ppm water, suggesting a smaller Nordic fraction of only $30 \%-50 \%$ (Stalder et al., 2019) compared to estimates based on heavy mineral assemblages and the $\mathrm{U} / \mathrm{Pb}$ age spectra of detrital zircons (Führing, 2017). Another example that the $\mathrm{OH}$ inventory records complementary information is revealed in Mesozoic sandstones such as the Buntsandstein (Lower Triassic), in which significant differences in $\mathrm{OH}$ were detected in a sequence, in which neither heavy mineral spectra nor $\mathrm{U} / \mathrm{Pb}$ ages revealed significant changes despite a clear change in sedimentary facies. The observed higher $\mathrm{OH}$ content in the lower sedimentary unit (Stalder et al., 2019) is in agreement with the interpretation that some plutons host the most $\mathrm{OH}$ rich quartz crystals in their roof region (Potrafke et al., 2020) and that $\mathrm{OH}$ 

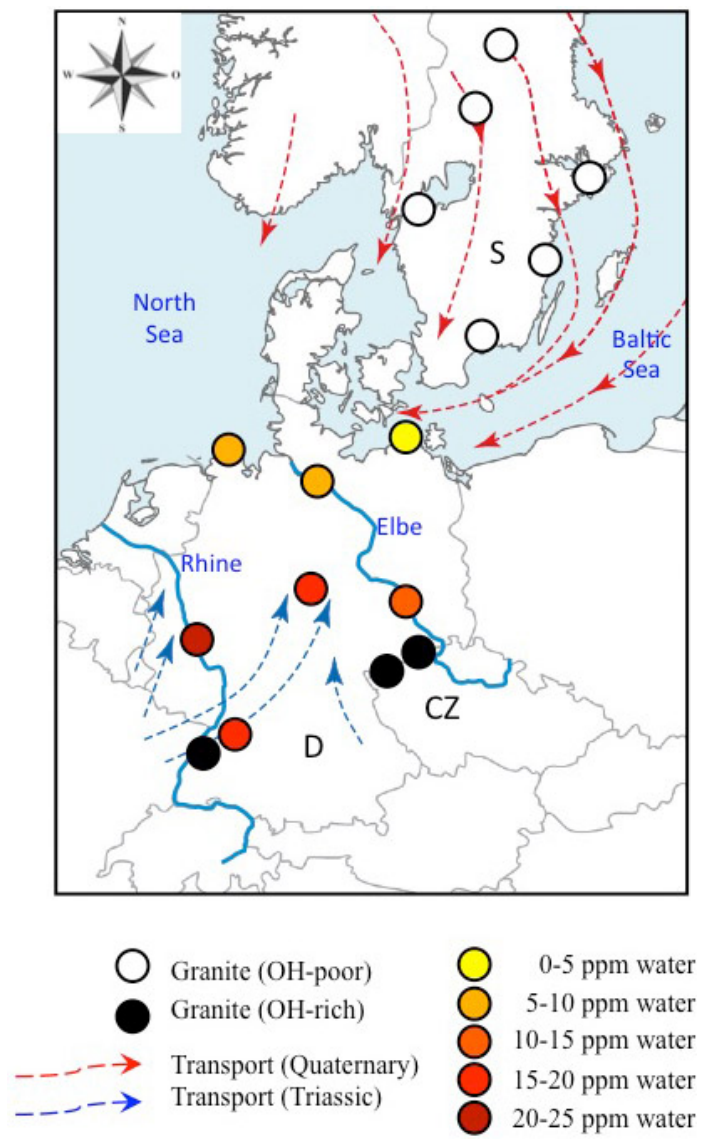

Figure 8. Geographical distribution of analysed sediments and Variscan granites from Central (Germany: D; Czech Republic: CZ) and Northern Europe (Sweden: S). Data for OH-rich (average > $20 \mathrm{wt}$ water) granites are from Stalder et al. (2017) and Potrafke et al. (2020), and those for $\mathrm{OH}-$ poor (average $<5 \mathrm{wt}$ ppm water) granites are from Stalder et al. (2017). Average $\mathrm{OH}$ contents for sedimentary quartz are colour-coded. Transport directions during the Mesozoic (Ziegler, 1990) and Quaternary (Eissmann, 1986) are indicated by blue and red arrows, respectively. Large recent rivers (Rhine and Elbe) are shown as blue lines and have transport directions to the north.

incorporation decreases with increasing pressure (Baron et al., 2015; Frigo et al., 2016). In addition, erosion of deeper parts of a pluton down to its roots takes place later, which increases the possibility that $\mathrm{OH}$ defects are lost during metamorphism. OH contents in quartz crystals in the sedimentary succession will thus show a depth profile which is inverse to the respective eroded plutonic body (Fig. 9).

\section{Conclusions and implications}

A combination of the different approaches to study $\mathrm{OH}$ point defects in quartz enables a link between understanding the incorporation behaviour depending on physical and chemical conditions, the evolution of igneous systems, and the re- cycling in sedimentary systems. Ideally, clusters of sedimentary quartz grains can be identified and then traced back to their possible sources and can give insights to their geological past. In detail the link may not be unequivocal, especially if the original sources are removed by erosion. However, a rough general estimate concerning the thermal history of the source can still be made. If the origin of quartz grains is unknown, one may divide them into three large classes: (1) pristine igneous and/or hydrothermal origin with moderate to high total $\mathrm{OH}$ and variable $\mathrm{LiOH} / \mathrm{AlOH}$, (2) mildly thermally annealed (late-stage) igneous grains with moderate to high total $\mathrm{OH}$ and low $\mathrm{LiOH} / \mathrm{AlOH}$, and (3) strongly dehydrated grains with very low $\mathrm{OH}$ contents and low $\mathrm{LiOH} / \mathrm{AlOH}$ such as metamorphic grains or grains from the middle part of pyroclastic density current deposits characterised by slow cooling. Different classes are not strictly divided and exhibit a continuous transition between each other: while group (1) covers nearly the whole range in Fig. 4, group (2) is confined to the low $\mathrm{LiOH} / \mathrm{AlOH}$ edge, and (3) is confined to the low $\mathrm{LiOH} / \mathrm{AlOH}$ and to the low $\mathrm{OH}$ corner. The very close match of $\mathrm{OH}$ contents of $250 \mathrm{wt}$ ppm water in quartz from high-pressure experiments $\leq 4 \mathrm{kbar}$ under water-saturated conditions in a granitic system (Potrafke et al., 2019) and the highest contents observed in natural grains (Jaeger et al., 2019) suggests that the natural processes can be realistically simulated by high-pressure experiments. Linking the sedimentary grains to quartz specimens found in situ (such as directly sampled from igneous bodies or hydrothermal veins and fissures) is not straightforward, and candidates that might be the precursors for the most $\mathrm{OH}$-rich sedimentary grains were not identified yet. Basically all hitherto identified grains from sediments with very high $(>100 \mathrm{wt}$ ppm water) $\mathrm{OH}$ contents (Fig. 1d) would belong to the abovedefined class (2) but otherwise cannot be linked to natural specimens found in situ, which either belong to class (1) and show a much higher $\mathrm{LiOH} / \mathrm{AlOH}$ (as the mimetic quartzes; Bambauer, 1961) or have lower total OH contents (Table 1). Possibly, the $\mathrm{OH}$-rich grains were originally formed with high $\mathrm{LiOH} / \mathrm{AlOH}$ and were later annealed at sufficiently low temperature (and/or over a sufficiently short time) so that $\mathrm{LiOH}$ was destroyed, but the high $\mathrm{OH}$ content was preserved. With respect to the low thermal stability of $\mathrm{LiOH}$ the available data led to a consensus that fully explains that $\mathrm{LiOH}$ is absent in old plutonic bodies and metamorphic rocks.

Generally, $\mathrm{OH}$ incorporation is probably controlled predominantly by the availability of $\mathrm{Li}$ and water (provided that also $\mathrm{Al}$ is present), and an increase in Li leads to a decrease in LiOH by the formation of dry LiAl defects (Frigo et al., 2016), and, further, an increase in water activity leads to an increase in total $\mathrm{OH}$. The observed trend on a larger scale suggests a general decrease in $\mathrm{OH}$ with pressure and depth - that is mainly driven by an unfavourable $\mathrm{Al}$ incorporation on the tetrahedral site (Stalder and Konzett, 2012; Frigo et al., 2016) - implying that quartz from large batholiths should exhibit less $\mathrm{OH}$ defects in their roots. Consequently, deep 

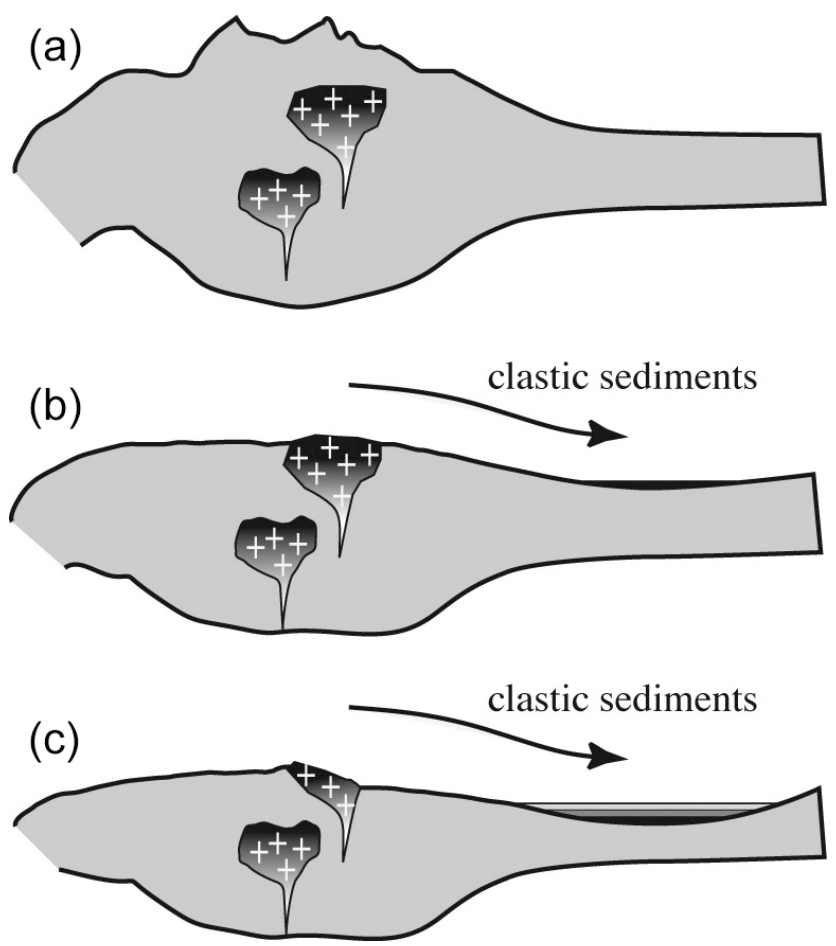

Figure 9. Sequence of schematic continental crust sections with granitic plutons (marked by crosses) that erode over time. In the sedimentary record the upper portion of a pluton is deposited as lower units (b) and the lower portion as upper units (c). Darker colours represent higher $\mathrm{OH}$ contents, taking into account that the $\mathrm{OH}$ incorporation exhibits a negative pressure trend and that lower parts of plutons are subjected to longer and more intense metamorphic overprint.

(late) erosion furnishes less $\mathrm{OH}$-rich quartz grains compared to shallow (early) erosion (Fig. 9). This effect is further reinforced by the longer (and stronger) subjection to metamorphic overprint of the more basal portions of the plutonic bodies.

In conclusion, $\mathrm{OH}$ defects in quartz may be used to quantify geological processes, provided that a sufficiently large data set is present.

1. A statistical distribution of $\mathrm{OH}$ defects in metamorphic rocks could be used as a geothermometer, in which a higher degree of equilibration between the individual grains is reached at higher temperature.

2. In pyroclastic density current deposits (ignimbrites) the distribution of $\mathrm{OH}$ defects can be modelled in terms of diffusional loss allowing for an estimate on depositional temperature and the timescales of long-lasting cooling.

3. In specific cases the classification low $\mathrm{OH}=$ old and high $\mathrm{OH}=$ young may be a valuable tool. However, the application as a geochronometer is generally not possible since $\mathrm{OH}$-rich grains primarily reflect their formation conditions independent of the age of the host rock, and $\mathrm{OH}$-rich grains may be preserved in old sedimentary rocks, such in the $1.4 \mathrm{Gyr}$ old Dala sandstone in Sweden.

4. Provided that a sufficiently large data set exists and that the different sources can be distinguished by their $\mathrm{OH}$ inventory, the quantification of mixing ratios of different reservoirs is possible.

\section{Open problems and further research directions}

Despite the progress during the past decade, several knowledge gaps persist. Further research directions could be addressed to (1) the formation and stability of hydrous defects during deformation, (2) experiments in a more narrow grid at $1-5 \mathrm{kbar}$, (3) the influence of high/low quartz transition, (4) experiments $<1 \mathrm{kbar}$ to verify the rapid increase in the low pressure regime and for application to volcanic rocks, (5) $\mathrm{Li}-\mathrm{H}$ exchange in quartz from volcanic samples for quantification of eruption timescales, and (6) the nature of the band at $3200 \mathrm{~cm}^{-1}$.

Other hitherto unsolved questions refer to the link between IR spectroscopy and other spectroscopic methods such as cathodoluminescence (CL) and optical stimulated luminescence spectroscopy (OSL). Despite several systematic studies a clear correlation between the spectral characteristics of IR and CL could so far not be established, and both methods seem to give complementary information (Müller et al., 2009; Stalder and Neuser, 2013; Potrafke et al., 2020). Very few studies combining IR and OSL were so far performed, and the existing data set does not reveal a clear correlation between IR and OSL characteristics. Hydrous point defects show a vague but barely significant positive correlation to the intensity of the OSL signal (Thamóné et al., 2020), and for molecular water (fluid inclusions) contrasting results - positive trends (Sharma et al., 2017) and no correlation (Thamóné et al., 2020) - were reported. The fact that for these methods the ideal grain size is different - typically $90-250 \mu \mathrm{m}$ for OSL (Rhodes, 2011) and 250-1000 $\mu \mathrm{m}$ for IR - is unfavourable for combining both methods for the same sample material.

Data availability. No data sets were used in this article.

Competing interests. The author declares that there is no conflict of interest.

Special issue statement. This article is part of the special issue "Probing the Earth: reviews of $\mathrm{OH}$ groups in anhydrous and hydrous minerals". It is not associated with a conference. 
Acknowledgements. This project was supported by the Austrian Science Fund (FWF): P29145-N34 and P33038-N. Over the past decade, many colleagues and students contributed significantly by critical discussions, by providing sample material and analytical facilities, and by performing experimental and analytical work, and they have helped to successfully perform current and previous projects on $\mathrm{OH}$ in quartz. In this context, I would like to thank Marzena Baron, Kjell Billström, Karel Breiter, Hilmar von Eynatten, Corinne Frigo, Christoph Hauzenberger, Dominik Jaeger, Jürgen Konzett, Thomas Ludwig, Guido Meinhold, Peter Mirwald, Rolf Dieter Neuser, Alexander Potrafke, Burkhard Schmidt, Henrik Skogby, Michael Strasser and many others for constructive cooperation. Hans Ulrich Bambauer is thanked for talking about his work. Axel Müller, Mike Jollands, and an anonymous reviewer are thanked for their thorough and constructive reviews.

Review statement. This paper was edited by István Kovács and reviewed by Axel Müller, Michael Jollands, and one anonymous referee.

\section{References}

Adams, S. J., Hawkes, G. E., and Curzon, E. H.: A solid state ${ }^{29} \mathrm{Si}$ nuclear magnetic resonance study of opal and other hydrous silicas, Am. Mineral., 76, 1863-1871, 1991.

Aines, R. D. and Rossman, G. R.: Water in minerals? A peak in the infrared, J. Geophys. Res., B89, 4059-4071, 1984.

Aines, R. D., Kirby, S. H., and Rossman, G. R.: Hydrogen speciation in synthetic quartz, Phys. Chem. Miner., 11, 204-212, 1984.

Bachheimer, J. P.: An investigation into hydrogen stability in synthetic, natural and air-swept synthetic quartz in air temperatures up to $1100^{\circ} \mathrm{C}$, J. Phys. Chem. Solids, 59, 831-840, 1998.

Balan, E., Refson, K., Blanchard, M., Delattre, S., Lazzeri, M., Ingrin, J., Mauri, F., Wright, K., and Winkler, B.: Theoretical infrared absorption coefficient of $\mathrm{OH}$ groups in minerals, Am. Mineral., 93, 950-953, https://doi.org/10.2138/am.2008.2889, 2008.

Bambauer, H. U.: Spurenelementgehalte und $\gamma$-Farbzentren in Quarzen aus Zerrklüften der Schweizer Alpen, Schweiz. Min. Petr. Mitt., 41, 335-369, 1961.

Bambauer, H. U., Brunner, G. O., and Laves, F.: WasserstoffGehalte in Quarzen aus Zerrklüften der Schweizer Alpen und Deutung ihrer regionalen Abhängigkeit, Schweiz. Min. Petr. Mitt., 42, 221-236, 1962.

Bambauer, H. U., Brunner, G. O., and Laves, F.: Merkmale des OH-Spektrums alpiner Quarze ( $3 \mu$-Gebiet), Schweiz. Min. Petr. Mitt., 43, 259-268, 1963.

Bambauer, H. U., Brunner, G. O., and Laves, F.: Light scattering of heat-treated quartz in relation to hydrogen-containing defects, Am. Mineral., 54, 718-724, 1969.

Baron, M. A., Stalder, R., Konzett, J., and Hauzenberger, C. A.: Formation conditions of quartz recorded by $\mathrm{OH}-$ point defects experimental and analytical approach, Phys. Chem. Miner., 42, 53-62, https://doi.org/10.1007/s00269-014-0699-4, 2015.

Biró, T., Kovács, I. J., Király, E., Falus, G., Karátson, D., Bendö, Z., Fancsik, T., and Sándorné, J. K.: Concentration of hydroxyl defects in quartz from various rhyolitic ignimbrite horizons: results from unpolarized micro-FTIR analyses on un- oriented phenocryst fragments, Eur. J. Mineral., 28, 313-327, https://doi.org/10.1127/ejm/2016/0028-2513, 2016.

Biró, T., Kovács, I. J., Karátson, D., Stalder, R., Király, E., Falus, G., Fancsik, T., and Sándorné, J. K.: Evidence for postdepositional diffusional loss of hydrogen in quartz phenocryst fragments within ignimbrites, Am. Mineral., 102, 1187-1201, https://doi.org/10.2138/am-2017-5861, 2017.

Breiter, K., Müller, A., Leichmann, J., and Gabasová, A.: Textural and chemical evolution of a fractionated granitic system: the Podlesí stock, Czech Republic, Lithos, 80, 323-345, https://doi.org/10.1016/j.lithos.2003.11.004, 2005.

Brown, R. N. and Kahan, A.: Optical absorption of irradiated quartz in the near i.r., J. Phys. Chem. Solids, 36, 467-476, https://doi.org/10.1016/0022-3697(75)90076-1, 1975.

Brunner, G. O., Wondratschek, H., and Laves, F.: Ultrarotuntersuchungen über den Einbau von $\mathrm{H}$ in natürlichem Quarz, Zeitschrift für Elektrochemie, 65, 735-750, 1961.

Carter, N. L., Christie, J. M., and Griggs, D. T.: Experimental deformation and recrystallization of quartz, J. Geol., 72, 687-733, 1964.

Chakraborty, D. and Lehmann, G.: Distribution of $\mathrm{OH}$ in synthetic and natural quartz crystals, J. Solid State Chem., 17, 305-311, 1976a.

Chakraborty, D. and Lehmann, G.: On the structure and orientations of hydrogen defects in natural and synthetic quartz crystals, Phys. Stat. Solidi A, 34, 467-474, https://doi.org/10.1002/pssa.2210340206, 1976b.

Charlier, B. L. A., Morgan, D. J., Wilson, C. J. N., Wooden, J. L., Allan, A. S. R., and Baker, J. A.: Lithium concentration gradients in feldspar and quartz record the final minutes of magma ascent in an explosive supereruption, Earth Planet. Sc. Lett., 319-320, 218-227, https://doi.org/10.1016/j.eps1.2011.12.016, 2012.

Chauviré, B., Rondeau, B., and Mangolg, N.: Near infrared signature of opal and chalcedony as a proxy for their structure and formation conditions, Eur. J. Mineral., 29, 409-421, https://doi.org/10.1127/ejm/2017/0029-2614, 2017.

Cohen, A. J.: Substitutional and interstitial aluminium impurity in quartz, structure and color center interrelationships, J. Phys. Chem. Solids, 13, 321-325, https://doi.org/10.1016/00223697(60)90016-0, 1960.

Cordier, P. and Doukhan, J. C.: Water speciation in quartz: a near infrared study, Am. Mineral., 76, 361-369, 1991.

Cordier, P., Boulogne, B., and Doukhan, J. C.: Water precipitation and diffusion in wet quartz and wet berlinite $\mathrm{AlPO}_{4}, \mathrm{Bull}$ Minéral., 111, 113-137, 1988.

Cordier, P., Weil, J. A., Howarth, D. F., and Doukhan, J. C.: Influence of the $(4 \mathrm{H})_{\mathrm{Si}}$ defect on dislocation motion in crystalline quartz, Eur. J. Mineral., 6, 17-22, 1994.

Doukhan, J. C. and Trépied, L.: Plastic deformation of quartz single crystals, Bull. Minéral., 108, 97-123, 1985.

Eissmann, L.: Quartärgeologie und Geschiebeforschung im Leipziger Land mit einigen Schlußfolgerungen zu Stratigraphie und Vereisungsablauf im Norddeutschen Tiefland, p. 105-133, in: Die Eiszeitgeschiebe in der Umgebung von Leipzig. Bestand, Herkunft, Nutzung und quartärgeologische Bedeutung, edited by: Richter, E., Baudenbacher, R., and Eissmann, L., Altenburger Naturwissenschaftliche Forschung, 3, 1-136, 1986 (in German) 
Elphick, S. C. and Graham, C. M.: The effect of hydrogen on oxygen diffusion in quartz: evidence for fast proton transients?, Nature, 335, 243-245, 1988.

Flörke, O. W., Flörke, U., and Giese, U.: Moganite. A new microcrystalline silica-mineral, N. Jb. Mineral. Abh., 149, 325-336, 1984.

Frey, M. and Ferreiro-Mählmann, R.: Alpine metamorphism of the Central Alps, Schweiz. Min. Petr. Mitt., 79, 135-154, 1999.

Frigo, C., Stalder, R., and Hauzenberger, C. A.: OH-defects in quartz in granitic systems doped with spodumene, tourmaline and/or apatite: experimental investigations at 5-20 kbar, Phys. Chem. Miner., 43, 717-729, https://doi.org/10.1007/s00269016-0828-3, 2016.

Frigo, C., Stalder, R., and Ludwig, T.: OH defects in coesite and stishovite during ultrahigh-pressure metamorphism of continental crust, Phys. Chem. Miner., 46, 77-89, https://doi.org/10.1007/s00269-018-0987-5, 2019.

Frondel, C.: Structural hydroxyl in chalcedony (Type B quartz), Am. Mineral., 67, 1248-1257, 1982.

Führing, P.: Provenienz und Verteilung rezenter Sande der Nordseeküste (West- bis Ostfriesland) und der Flüsse Elbe, Weser und Ems, MSc-thesis, University of Göttingen, Göttingen, Germany, 167 pp., 2017 (in German with English abstract).

Gerretsen, J., Paterson, M. S., and McLaren, A. C.: The uptake and solubility of water in quartz at elevated pressure and temperature, Phys. Chem. Miner., 16, 334-342, 1989.

Griggs, D. T. and Blacic, J. D.: Quartz: anomalous weakness of synthetic crystals, Science, 147, 292-295, 1965.

Griggs, D. T., Blacic, J. D., Christie, J. M., McLaren, A. C., and Frank, F. C.: Hydrolytic weakening of quartz crystals, Science, 152, 674, 1966.

Halliburton, L. E., Koumvakalis, N., Markes, M. E., and Martin, J. J.: Radiation effects in crystalline $\mathrm{SiO}_{2}$ : the role of aluminium, J. Appl. Phys., 52, 3565-3574, https://doi.org/10.1063/1.329138, 1981.

Hardgrove, C. and Rogers, D.: Thermal infrared and Raman microspectroscopy of moganite-bearing rocks, Am. Mineral., 98, 78-84, https://doi.org/10.2138/am.2013.4152, 2013.

Heaney, P. J. and Post, J. E.: The widespread distribution of a novel silica polymorph in microcrystalline quartz varieties, Science, 255, 441-443, https://doi.org/10.1126/science.255.5043.441, 1992.

Jaeger, D., Stalder, R., Masago, H., and Strasser, M.: OH defects in quartz as a provenance tool: application to fluvial and deep marine sediments from SW Japan, Sed. Geol., 388, 66-80, https://doi.org/10.1016/j.sedgeo.2019.05.003, 2019.

Jollands, M. C., Blanchard, M., and Balan, E.: Structure and theoretical infrared spectra of $\mathrm{OH}$ defects in quartz, Eur. J. Mineral., 32, 311-323, https://doi.org/10.5194/ejm-32-311-2020, 2020a.

Jollands, M. C., Ellis, B., Tollan, P., and Müntener, O.: An eruption chronometer based on experimentally determined $\mathrm{H}-\mathrm{Li}$ and $\mathrm{H}-\mathrm{Na}$ diffusion in quartz applied to the Bishop Tuff, Earth Planet. Sc. Lett., 551, 116560, https://doi.org/10.1016/j.epsl.2020.116560, 2020b.

Jung, L.: High purity natural quartz, Part I: High purity natural quartz for industrial use, Quartz Technology Inc., Liberty Corner, New Jersey, 538 pp., 1992 a.
Jung, L.: High purity natural quartz, Part II: High purity natural quartz markets for supplier and users, Quartz Technology Inc., Liberty Corner, New Jersey, 131 pp., 1992b.

Karampelas, S., Fritsch, E., Zorba, T., Paraskevopoulos, K. M., and Sklavounos, S.: Distinguishing natural from synthetic amethyst: the presence and shape of the $3595 \mathrm{~cm}^{-1}$ peak, Mineral. Petrol. 85, 45-52, https://doi.org/10.1007/s00710-005-0101-9, 2005.

Kats, A.: Hydrogen in alpha quartz, Philips Research Reports, 17, 133-279, 1962.

Kronenberg, A. K. and Kirby, S. H.: Ionic conductivity of quartz: DC time dependence and transition in charge carriers, Am. Mineral., 72, 739-747, 1987.

Kronenberg, A. K., Kirby, S. H., Aines, R. D., and Rossman, G. R.: Solubility and diffusional uptake of hydrogen in quartz at high water pressures: implications for hydrolytic weakening, J. Geophys. Res., B91, 12723-12744, 1986.

Kronenberg, A. K., Hasnan, H. F. B., Holyoke III, C. W., Law, R. D., Liu, Z., and Thomas, J. B.: Synchrotron FTIR imaging of $\mathrm{OH}$ in quartz mylonites, Solid Earth, 8, 1025-1045, https://doi.org/10.5194/se-8-1025-2017, 2017.

Langer, K. and Flörke, O. W.: Near infrared absorption spectra $\left(4000-9000 \mathrm{~cm}^{-1}\right)$ of opals and the role of "water" in these $\mathrm{SiO}_{2}-\mathrm{nH}_{2} \mathrm{O}$ minerals, Fortschr. Mineral., 52, 17-51, 1974.

Libowitzky, E. and Rossman, G. R.: An IR calibration for water in minerals, Am. Mineral., 82, 1111-1115, https://doi.org/10.2138/am-1997-11-1208, 1997.

London, D.: Experimental phase equilibria in the system $\mathrm{LiAlSiO}_{4}$ $\mathrm{SiO}_{2}-\mathrm{H}_{2} \mathrm{O}$ : a petrogenetic grid for lithium-rich pegmatites, Am. Mineral., 69, 995-1004, 1984.

Mackwell, S. J. and Paterson, M. S.: Water related diffusion and deformation effects in quartz at pressures of 1500 and $300 \mathrm{MPa}$ In: Schock, R.N. (Ed.) Point defects in minerals, Am. Geophys. Union, Geophys. Monogr., 31, 141-150, 1985.

McConnell, J. D. C., Lin, J. S., and Heine, V.: The solubility of $[4 \mathrm{H}]_{\mathrm{Si}}$ defects in a-quartz and their role in the formation of molecular water and related weakening on heating, Phys. Chem. Miner., 22, 357-366, https://doi.org/10.1007/BF00213332, 1995.

Merritt, E.: Ueber den Dichroismus von Kalkspath, Quarz und Turmalin für ultrarothe Strahlen, Annalen der Physik und Chemie, 55, 49-64, 1895.

Miyoshi, N., Yamaguci, Y., and Maino, K.: Successive zoning of Al and $\mathrm{H}$ in hydrothermal vein quartz, Am. Mineral., 90, 310-315, 2005.

Müller, A. and Koch-Müller, M.: Hydrogen speciation and trace element contents of igneous, hydrothermal and metamorphic quartz from Norway, Mineral. Mag., 73, 569-583, https://doi.org/10.1180/minmag.2009.073.4.569, 2009.

Müller, A., Wiedenbeck, M., van den Kerkhof, A. M., Kronz, A., and Simon, K.: Trace elements in quartz - a combined electron microprobe, secondary ion mass spectrometry, laser ablation ICP-MS, and cathodoluminescence study, Eur. J. Mineral., 15, 747-763, https://doi.org/10.1127/09351221/2003/0015-0747, 2003.

Müller, A., van den Kerkhof, A. M., Behr, H.-J., Kronz, A., and Koch-Müller, M.: The evolution of late-Hercynian granites and rhyolites documented by quartz - a review, Earth Environ. Sci. Trans. Royal Soc. Edinburgh, 100, 185-204, https://doi.org/10.1017/S1755691009016144, 2009. 
Niimi, N., Aikawa, N., and Shinoda, K.: The infrared absorption band at $3596 \mathrm{~cm}^{-1}$ of the recrystallized quartz from Mt. Takamiyama, southwest Japan, Mineral. Mag., 63, 693-701, https://doi.org/10.1180/002646199548853, 1999.

Nuttall, R. H. D. and Weil, J. A.: The magnetic properties of the oxygenhole aluminium centers in crystalline $\mathrm{SiO}_{2}$. II. $\left[\mathrm{AlO}_{4} / \mathrm{H}^{+}\right]$and $\left[\mathrm{AlO}_{4} / \mathrm{Li}^{+}\right]$, Can. J. Phys., 59, 1709-1718, https://doi.org/10.1139/p81-228, 1981.

Paterson, M. S.: The thermodynamics of water in quartz, Phys. Chem. Miner., 13, 245-255, 1986.

Potrafke, A., Stalder, R., Schmidt, B. C., and Ludwig, T.: OH defect contents in quartz in a granitic system at $1-5 \mathrm{kbar}$, Contrib. Mineral. Petrol., 174, 98, https://doi.org/10.1007/s00410-019-16320, 2019.

Potrafke, A., Breiter, K., Ludwig, T., Neuser, R. D., and Stalder, R.: Variations of $\mathrm{OH}$ defects and chemical impurities in quartz within igneous bodies, Phys. Chem. Miner., 47, 24, https://doi.org/10.1007/s00269-020-01091-w, 2020.

Purton, J., Jones, R., Heggie, M., Öberg, S., and Catlow, C. R. A.: LDF pseudopotential calculations of the a-quartz structure and hydrogarnet defect, Phys. Chem. Miner., 18, 389-392, https://doi.org/10.1007/BF00199421, 1992.

Rhodes, E. J.: Optically stimulated luminescence dating of sediments over the past 200000 years, Ann. Rev. Earth Planet. Sc., 39, 461-488, https://doi.org/10.1146/annurev-earth-040610133425, 2011.

Ronov, A. B. and Yaroshevski, A. A.: Chemical composition of the Earth's crust, in: The Earths's crust and upper mantle, edited by: Hart, P. J., Geophysical Monograph Series, Amer. Geophys. Union, 13, 37-57, https://doi.org/10.1029/GM013p0037, 1969.

Rosa, A. L., El-Barbary, A. A., Heggie, M. I., and Briddon, P. R.: Structural and thermodynamic properties of water related defects in a-quartz, Phys. Chem. Miner., 32, 323-331, https://doi.org/10.1007/s00269-005-0005-6, 2005.

Rovetta, M. R.: Experimental and spectroscopic constraints on the solubility of hydroxyl in quartz, Phys. Earth Planet. Int., 55, 326334, 1989.

Rovetta, M. R., Holloway, J. R., and Blacic, J. D.: Solubility of hydroxyl in natural quartz annealed in water at $900^{\circ} \mathrm{C}$ and $1.5 \mathrm{GPa}$, Geophys. Res. Lett., 13, 145-148, 1986.

Rovetta, M. R., Blacis, J. D., Hervig, R. L., and Holloway, J. R.: An experimental study of hydroxyl in quartz using infrared spectroscopy and ion microprobe techniques, J. Geophys. Res., 94B, 5840-5850, 1989.

Roy, R. and Osborn, E. F.: The system lithium metasilicatespodumene-silica, J. Am. Cer. Soc., 71, 2086-2095, 1949.

Shaffer, E. W., Sang, J. S. L., Cooper, A. R., and Heuer, A. H.: Diffusion of tritiated water in $\beta$-quartz, in: Geochemical Transport and Kintetics, edited by: Hofmann, A. W., Giletti, B. J., Yoder, H. S., and Yund, R. A., Carnegie institution Washington, Publication 634, 131-138, 1974.

Sharma, S. K., Chawla, S., Sastry, M. D., Gaonkar, M., Mane, S., Balaram, V., and Singhvi, A. K.: Understanding the reasons for variations in luminescence sensitivity of natural quartz using spectroscopic and chemical studies, Proc. Ind. Nat. Sci. Acad., 83, 645-653, https://doi.org/10.16943/ptinsa/2017/49024, 2017

Staats, P. A. and Kopp, O. C.: Studies of the origin of the $3400 \mathrm{~cm}^{-1}$ region infrared bands of synthetic and natural $\alpha$-quartz, J. Phys.
Chem. Solids, 35, 1029-1033, https://doi.org/10.1016/S00223697(74)80118-6, 1974.

Stalder, R.: OH-defect content in detrital quartz grains as an archive for crystallization conditions, Sed. Geol., 307, 1-6, https://doi.org/10.1016/j.sedgeo.2014.04.002, 2014.

Stalder, R. and Konzett, J.: OH-defects in quartz in the system quartz - albite - water and granite - water between 5 and $25 \mathrm{kbar}$, Phys. Chem. Miner., 39, 817-827, https://doi.org/10.1007/s00269-012-0537-5, 2012.

Stalder, R. and Neuser, R. D.: OH-defects in detrital quartz grains: potential for application as tool for provenance analysis and overview over crustal average, Sed. Geol., 294, 118-126, https://doi.org/10.1016/j.sedgeo.2013.05.013, 2013.

Stalder, R., Potrafke, A., Billström, K., Skogby, H., Meinhold, G., Gögele, C., and Berberich, T.: OH defects in quartz as monitor for igneous, metamorphic, and sedimentary processes, Am. Mineral., 102, 1832-1842, https://doi.org/10.2138/am-2017-6107, 2017.

Stalder, R., von Eynatten, H., Costamoling, J., Potrafke, A., Dunkl, I., and Meinhold, G.: $\mathrm{OH}$ in detrital quartz grains as tool for provenance analysis: case studies on various settings from Cambrian to Recent, Sed. Geol., 389, 121-126, https://doi.org/10.1016/j.sedgeo.2019.06.001, 2019.

Suzuki, S. and Nakashima, S.: In-situ IR measurements of $\mathrm{OH}$ species in quartz at high temperatures, Phys. Chem. Miner., 26, 217-225, https://doi.org/10.1007/s002690050180, 1999.

Tailby, N. D., Cherniak, D., and Watson, E. B.: Al diffusion in quartz, Am. Mineral., 103, 839-847, https://doi.org/10.2138/am2018-5613, 2018.

Thamóné, B. E., Füri, J., Kovács, I. J., Biró, T., Király, E., Nagy, A., Törökné Sinka, M., Kónya, P., Mészárosné Turi, J., and Vígh, C.: Characteristics of quartz separates of different formations in Hungary from the aspect of OSL dating, Bull. Hung. Geol. Soc., 150, 61-80, https://doi.org/10.23928/foldt.kozl.2020.150.1.61, 2020 (in Hungarian with English abstract).

Thomas, S. M., Koch-Müller, M., Reichart, P., Rhede, D., Thomas, R., and Wirth, R.: IR calibrations for water determination in olivine, $\mathrm{r}-\mathrm{GeO}_{2}$ and $\mathrm{SiO}_{2}$ polymorphs, Phys. Chem. Miner., 36, 489-509, https://doi.org/10.1007/s00269-009-0295-1, 2009.

Tollan, P., Ellis, B., Troch, J., and Neukampf, J.: Assessing magmatic volatile equilibria through FTIR spectroscopy of unexposed melt inclusions and their host quartz: a new technique and application to the Mesa Falls Tuff, Yellowstone, Contrib. Mineral. Petrol., 174, 24, https://doi.org/10.1007/s00410-019-1561y, 2019.

Wedepohl, K. H.: The composition of the continental crust, Geochim. Cosmochim. Ac., 59, 1217-1232, https://doi.org/10.1016/0016-7037(95)00038-2, 1995.

Wenk, E.: Plagioklas als Indexmineral in den Zentralalpen. Die Paragenese Calcit - Plagioklas, Schweiz. Min. Petr. Mitt., 42, 139$152,1962$.

Winkler, H. G. F.: Synthese und Kristallstruktur des Eucryptits, Acta Cryst., 1, 27-34, 1948.

Yurimoto, H., Kurosawa, M., and Sueno, S.: Hydrogen analysis in quartz crystals and quartz glasses by secondary ion mass spectrometry, Geochim. Cosmochim. Ac., 53, 751-755, 1989.

Ziegler, P. A.: Geological Atlas of Western and Central Europe, Shell Internationale Petroleum Maatschappij B.V., The Hague, 239 pp., 1990. 